\title{
A history of biological control in Canadian forests, 1882-2014
}

\author{
Chris J.K. MacQuarrie, ${ }^{1}$ D.B. Lyons, M. Lukas Seehausen, Sandy M. Smith
}

\begin{abstract}
Biological control has been an important tactic in the management of Canadian forests for over a century, but one that has had varied success. Here, we review the history of biological control programmes using vertebrate and invertebrate parasitoids and predators against insects in Canadian forests. Since roughly 1882, 41 insect species have been the target of biological control, with approximately equal numbers of both native and non-native species targeted. A total of 161 species of biological control agents have been released in Canadian forests, spanning most major orders of insects, as well as mites and mammals. Biological control has resulted in the successful suppression of nine pest species, and aided in the control of an additional six species. In this review, we outline the chronological history of major projects across Canadian forests, focussing on those that have had significant influence for the development of biological control. The historical data clearly illustrate a rise and fall in the use of biological control as a tactic for managing forest pests, from its dominance in the 1940s and 1950s to its current low level. The strategic implementation of these biological control programmes, their degree of success, and the challenges faced are discussed, along with the discipline's shifting relationship to basic science and the environmental viewpoints surrounding its use.
\end{abstract}

\section{Introduction}

Biological control has been an important tactic in the management of Canadian forests over the past century, but one with varied success. Strictly speaking, the idea of using natural enemies or biological control to manage forest pests arose during the late 1800 s with the earliest programmes directed against pests in both Canada and the United States of America. In the United States of America, Thanasimus formicarius Linnaeus (Coleoptera: Cleridae) was introduced from Germany to control an outbreak of native southern pine beetle, Dendroctonus frontalis (Zimmerman) (Coleoptera: Curculionidae) in 1892 (Furniss 2010), and in Canada the parasitoid Trichogramma minutum Riley (Hymenoptera: Trichogrammatidae) was introduced near London,
Ontario, Canada in 1882 for use against the imported currantworm, Nematus ribesii (Scopoli) (Hymenoptera: Tenthredinidae), a pest of woody plants in the genus Ribes Linnaeus (Grossulariaceae) (Beirne and Kelleher 1973). Unfortunately, neither of these early attempts was considered successful, perhaps foreshadowing some of the difficulties to be faced by Canadian biological control programmes over the coming years.

The resounding success of the introduction of the vedalia beetle, Rodolia cardinalis Mulsant (Coleoptera: Coccinellidae), into California, United States of America around 1888 to control the non-native cottony cushion scale, Icerya purchasi Maskell (Hemiptera: Monophlebidae), launched many of the early biological control research programmes across North America (Thompson 1939; Balch 1960). Due to the Palaearctic origin

Received 8 January 2015. Accepted 8 July 2015. First published online 14 January 2016.

C.J.K. MacQuarrie, ${ }^{\mathbf{1}}$ Natural Resources Canada, Canadian Forest Service, Great Lakes Forestry Centre, 1219 Queen St. East, Sault Ste. Marie, Ontario, P6A 2E5, Canada

D.B. Lyons, Natural Resources Canada Canadian Forest Service, Great Lakes Forestry Centre, 1219 Queen St. East, Sault Ste. Marie, Ontario, P6A 2E5, Canada

M. Lukas Seehausen, Faculty of Forestry University of Toronto, 33 Willcocks St., Toronto, Ontario, M5S 3B3, Canada

S.M. Smith, Faculty of Forestry, University of Toronto, 33 Willcocks St., Toronto, Ontario, M5S 3B3, Canada

${ }^{1}$ Corresponding author (email: christian.macquarrie@canada.ca).

Langor, D.W. and Alfaro, R.I. (eds.) Forest Entomology in Canada: Celebrating a Century of Science Excellence doi:10.4039/tce.2015.66 
of the pests, many of these projects were carried out in collaboration with international institutes such as the Commonwealth Agricultural Bureaux (now CABI) (McGugan and Coppel 1962; Reeks and Cameron 1971; Kelleher and Hulme 1984; Mason and Huber 2002; Mason and Gillespie 2013). In the following review, we define biological control as the manipulation of natural enemies (vertebrate, invertebrate, or microbial) to reduce pest populations below an acceptable level of damage (van Driesche et al. 2008), and focus solely on the use of arthropods and vertebrate animals. Microbes are dealt with in a related review (van Frankenhuyzen et al. 2015).

Almost all biological control programmes have targeted what we now call invasive alien species; i.e., organisms not native to North America but with the potential to cause economic or ecological damage to important native plants or ecosystems. Here, we have elected to avoid the word "invasive", and instead refer to species that have inadvertently or intentionally been introduced into North America since about 1500 as non-native (Langor et al. 2014). As well, we have chosen to adopt the term "agent" throughout when referring to natural enemies used in biological control programmes, and "target" for organisms that cause damage or are subjects of suppression (sensu Eilenberg et al. 2001). "Target" is used in place of "pest" to avoid confusion because not all target species in programmes have been considered important pests, or even if they were in the past, may not be so today.

Canadian biological control programmes have used a range of tactics to exploit natural enemies and reduce pest damage in forests, including the three formally recognised as introduction, augmentation, and conservation biological control (van Driesche et al. 2008). All three tactics have been investigated in Canadian forests, but the most common has been introduction biological control. Classical biological control, or the intentional introduction of a non-native agent against a non-native target (Greathead 1994), is often the principal form of introduction, where a non-native biological control agent is collected from the same home range as that of the non-native target, and then released into the new habitat where the nonnative target has become established, with the aim of re-establishing an "old host-natural enemy association". A variation on this introduction approach is the attempt to create a "new host-natural enemy association", either through the relocation of a non-native agent from outside of Canada against a native Canadian target, or through the relocation of a native agent against a non-native target, both within Canada. The basis for these two tactics rests on the expectation that such a new association will significantly reduce the target host population (Eilenberg et al. 2001). A final version of the introduction strategy is the simple translocation of an agent (non-native or native) from a site where it is well established to a new area where it is absent or in very low numbers, both within Canada. In this case, the goal is to exploit an already existing effective relationship between the agent and the target, which for some reason varies across the target's geographic range. Regardless of the agent's or target's origin, all introduction strategies retain the underlying concept of introducing natural enemies to a new geographic location with the expectation of permanent establishment.

Conservation biological control has the goal of retaining or sustaining natural agent populations in an area so that pest outbreaks will be prevented or shortened and their impacts lessened. This strategy can include managing for diverse vegetation types, forest stand structures, and age class distributions, as well as reducing intensive forest management practices such as pesticide applications (van Driesche et al. 2008). Although the vast expanses of naturally forested regions in Canada seem to provide a prime target for this approach in biological control, few programmes have been conducted to date.

Canada has been a leader in developing methods for augmentation biological control. This strategy focusses on increasing agent populations that are already present, through mass rearing and release, either with the intent for the build-up of agents (inoculative release) or for their repeated application (inundative release). In inoculative releases, agents are meant to suppress the target and persist over one season, whereas in inundative releases, agents are intended to suppress a target and not persist (van Driesche et al. 2008). While most of the introduction programmes in Canada have made use of inoculative releases during their early stages (because it has always been necessary to rear agents in the laboratory in order to obtain sufficient numbers 
for release and establishment), repeated, inoculative biological control releases for seasonal augmentation have had limited scope in Canadian forests. In contrast, inundative releases have shown great potential for managing at least one native forest target in Canada.

Interpreting success in the context of Canadian biological control programmes has always been a challenge. Too often, success stories have been the only ones reported, and, in many cases, projects originally deemed successful, have later been labelled as unsuccessful (e.g., Hall et al. 1980; Hopper and Roush 1993; Gurr and Wratten 2000). Assessment is also made difficult when one considers that potentially effective techniques developed and tested during research, have often never been made operational (e.g., Mills 1983; Smith et al. 1990). This, combined with the fact that non-target impacts have rarely been assessed in Canada (even though they may have been shown in the United States of America) (e.g., Timms et al. 2011), suggests that criteria for measuring success in biological control lack consistency. In this review, we have divided the last 130 years into four general eras and taken a chronological approach to examine biological control programmes in Canadian forests. The success in each case is interpreted with respect to the activities and goals of the era. In the final section, we discuss the broader implications in terms of approach, implementation, success, and relationship to the underlying science.

\section{Summary of agents released in Canadian forests}

Since 1882, 41 forest insect species have been the target of biological control programmes in Canadian forests (Table 1). The native oak looper, Lambdina fiscellaria somniaria (Hulst) (Lepidoptera: Geometridae), was originally identified as a separate target, but because this subspecies is now considered a polymorphic form of the native hemlock looper, L. fiscellaria (Guenée) (Sperling et al. 1999), these two species have been combined here. Of the 41 targets, slightly more than half were non-native $(n=20)$ versus native $(n=18)$. The origin of the remaining three targets (Holarctic versus adventive) is difficult to assign (see The early era: 1882-1945).
Of the 20 non-native targets, all but two were of European origin (Table 1), the exceptions being: the emerald ash borer, Agrilus planipennis Fairmaire (Coleoptera: Buprestidae), native to Asia (Keever et al. 2012); and the satin moth, Leucoma salicis (Linnaeus) (Lepidoptera: Lymantriidae), which has an unknown distribution (but suspected to be Palaearctic).

A total of 158 agents have been released in biological control programmes against forest insects in Canada (Table 1). Of these, 28 species were released against multiple targets, the most frequent being: Drino bohemica Mesnil (Diptera: Tachinidae) against 12 targets; Dahlbominus fuscipennis (Zetterstedt) (Hymenoptera: Eulophidae) and Pleolophus basizonus (Gravenhorst) (Hymenoptera: Ichneumonidae) both released against seven targets; and Exenterus abruptorius (Thunberg) (Hymenoptera: Ichneumonidae), E. amictorius (Panzer), and T. minutum, each released against five targets (Table 1; Fig. 3).

The release of biological control agents in Canada began during the late 1880 s, peaked in the 1940s, declined dramatically during the 1960s, and remained low until the last decade when it fell again (Fig. 1). A similar trend is seen for both number of species targeted (Fig. 1) and number of agents released (Fig. 2). Parasitoids (i.e., insects of which the immatures feed on other arthropods, eventually killing them; after Godfray 1994) dominated those agents released in Canadian forests over all decades, while predators were somewhat important only during the 1950s and 1960s (Fig. 2). The species of parasitoids and predators released span seven taxonomic orders, but are dominated by the order Hymenoptera (Table 2). Only two agents have not been insects; a predatory mite, a species of Balaustium Heyden (Arachnida: Trombidiformes: Erythraeidae), introduced to Québec, Canada from Pakistan in 1967 against the non-native balsam woolly adelgid, Adelges piceae (Ratzeburg) (Hemiptera: Adelgidae) (Clark et al. 1971), and the masked shrew, Sorex cinereus Kerr (Mammalia: Soricidae), introduced into Newfoundland from New Brunswick, Canada in 1958 as a predator of the larch sawfly, Pristiphora erichsonii (Hartig) (Hymenoptera: Tenthredinidae) (Buckner 1959).

By far the majority of agents used for biological control in Canadian forests have been non-native 
Table 1. Native and non-native forest insect species targeted for biological control in Canadian forests between 1880 and 2014, and the agents released against each species. Species names follow current taxonomy. Unless indicated, where only the genus name is given denotes that an unidentified species was released.

\begin{tabular}{|c|c|c|c|c|}
\hline \multicolumn{3}{|c|}{ Target } & \multicolumn{2}{|l|}{ Agent } \\
\hline Species & Common name & Native range & Species & Origin of collections \\
\hline $\begin{array}{l}\text { Acantholyda erythrocephala } \\
\quad \text { (Linnaeus) } \\
\text { (Hymenoptera: Pamphiliidae) }\end{array}$ & Pine false webworm & Europe & $\begin{array}{l}\text { Myxexoristops hertingi Mesnil (Diptera: Tachinidae) } \\
\text { Trichogramma minutum Riley (Hymenoptera: Trichogrammatidae) } \\
\text { Trichogramma platneri Nagarkatti (Hymenoptera: } \\
\text { Trichogrammatidae) }\end{array}$ & $\begin{array}{l}\text { Europe } \\
\text { North America } \\
\text { North America }\end{array}$ \\
\hline $\begin{array}{l}\text { Adelges piceae (Ratzeburg) } \\
\text { (Hemiptera: Adelgidae) }\end{array}$ & Balsam woolly adelgid & Europe & $\begin{array}{l}\text { Adalia conglomerata (Linnaeus) (Coleoptera: Coccinellidae) } \\
\text { Adalia tetraspilota (Hope) (Coleoptera: Coccinellidae) } \\
\text { Aphidecta obliterata (Linnaeus) (Coleoptera: Coccinellidae) } \\
\text { Aphidoletes thompsoni Möhn (Diptera: Cecidomyiidae) } \\
\text { Balaustium Heyden (Trombidiformes: Erythraeidae) } \\
\text { Cnemodon* Schönherr (Diptera: Syrphidae) } \\
\text { Coccinella luteopicta (Mulsant) (Coleoptera: Coccinellidae) } \\
\text { Coccinella septempunctata Linnaeus (Coleoptera: Coccinellidae) } \\
\text { Cremifania nigrocellulata Czerny (Diptera: Chamaemyiidae) } \\
\text { Diomus pumilio Weise (Coleoptera: Coccinellidae) } \\
\text { Exochomus quadripustulatus (Linnaeus) (Coleoptera: Coccinellidae) } \\
\text { Harmonia eucharis (Mulsant) (Coleoptera: Coccinellidae) } \\
\text { Harmonia expallida (Weise) (Coleoptera: Coccinellidae) } \\
\text { Hemerobius nitidulus Fabricius (Neuroptera: Hemerobiidae) } \\
\text { Hemerobius stigma Stephens (Neuroptera: Hemerobiidae) } \\
\text { Laricobius erichsonii Rosenhauer (Coleoptera: Derodontidae) } \\
\text { Leucopis atratula Ratzeburg (Diptera: Chamaemyiidae) } \\
\text { Leucopis Meigen (Diptera: Chamaemyiidae) } \\
\text { Leucopis melanopus Tanasijtshuk (Diptera: Chamaemyiidae) (or near) } \\
\text { Leucopis obscura Haliday (Diptera: Chamaemyiidae) (or near) } \\
\text { Leucopis obscura Haliday (Diptera: Chamaemyiidae) } \\
\text { Lipoleucopis praecox de Meijère (Diptera: Chamaemyiidae) } \\
\text { Priscibrumus lituratus (Gorham) (Coleoptera: Coccinellidae) } \\
\text { Priscibrumus uropygialis (Mulsant) (Coleoptera: Coccinellidae) } \\
\text { Scymnus } \dagger \text { impexus (Mulsant) (Coleoptera: Coccinellidae) } \\
\text { Tetraphleps abdulghani Ghauri (Hemiptera: Anthocoridae) } \\
\text { Tetraphleps raoi Ghauri (Hemiptera.: Anthocoridae) }\end{array}$ & $\begin{array}{l}\text { Asia } \\
\text { Asia } \\
\text { Europe } \\
\text { Europe } \\
\text { Asia } \\
\text { Europe } \\
\text { Asia } \\
\text { Asia } \\
\text { Europe } \\
\text { Australia } \\
\text { Europe } \\
\text { Asia } \\
\text { Asia } \\
\text { Europe } \\
\text { Europe } \\
\text { Europe } \\
\text { Europe } \\
\text { North America } \\
\text { Europe } \\
\text { Europe } \\
\text { Europe } \\
\text { Europe } \\
\text { Asia } \\
\text { Asia } \\
\text { Europe } \\
\text { Asia } \\
\text { Asia }\end{array}$ \\
\hline $\begin{array}{l}\text { Agrilus planipennis Fairmaire } \\
\text { (Coleoptera: Buprestidae) }\end{array}$ & Emerald ash borer & Asia & $\begin{array}{l}\text { Phasgonophora sulcata Westwood (Hymenoptera: Chalcidae) } \\
\text { Tetrastichus planipennisi Yang (Hymenoptera: Eulophidae) }\end{array}$ & $\begin{array}{l}\text { North America } \\
\text { Asia }\end{array}$ \\
\hline $\begin{array}{l}\text { Carulaspis visci (Schrank) } \\
\text { (Hemiptera: Diaspididae) }\end{array}$ & Juniper scale & Europe & Encarsia lounsburyi (Berlese and Paoli) (Hymenoptera: Aphelinidae) & North America \\
\hline $\begin{array}{l}\text { Choristoneura fumiferana } \\
\text { (Clemens) } \\
\text { (Lepidoptera: Tortricidae) }\end{array}$ & Spruce budworm & North America & $\begin{array}{l}\text { Agria affinis (Fallén) (Diptera: Sarcophagidae) } \\
\text { Agria housei Shewell (Diptera: Sarcophagidae) } \\
\text { Apanteles murinanae Capec and Zwölfer (Hymenoptera: Braconidae) }\end{array}$ & $\begin{array}{l}\text { North America } \\
\text { North America } \\
\text { Europe }\end{array}$ \\
\hline
\end{tabular}


Table 1. Continued

Target

$\underline{\text { Species }}$

Common name

Native range

Larch casebearer

Europe

(Hübner)

(Lepidoptera: Coleophoridae)

\section{Coleophora serratella}

Linnaeus

Birch casebearer

(Lepidoptera: Coleophoridae)

Coleotechnites starki

(Freeman)

Lodgepole needle miner North America
(Lepidoptera: Gelechiidae)
Agent

Origin of collections

Apechthis rufata (Gmelin) (Hymenoptera: Ichneumonidae)

Bassus tumidulus (Nees) (Hymenoptera: Braconidae)

Campoplex rufipes Gravenhorst (Hymenoptera: Ichneumonidae)

Cephaloglypta murinanae (Bauer) (Hymenoptera: Ichneumonidae)

Ceromasia auricaudata Townsend (Diptera: Tachinidae)

Cyzenis incrassata (Smith) (Diptera: Tachinidae)

Diadegma chrysostictos (Gmelin) (Hymenoptera: Ichneumonidae)

Dirophanes maculicornis (Wesmael) (Hymenoptera: Ichneumonidae)

Iseropus coelebs (Walsh) (Hymenoptera: Ichneumonidae)

Itoplectis maculator (Fabricius) (Hymenoptera: Ichneumonidae)

Lissonota Gravenhorst (Hymenoptera: Ichneumonidae)

Macrocentrus resinellae (Linnaeus) (Hymenoptera: Ichneumonidae)

Meteorus cameroni Shenefelt (Hymenoptera: Braconidae)

Phytodietus fumiferanae Rohwer (Hymenoptera: Ichneumonidae)

Phytodietus polyzonias (Forster) (Hymenoptera: Ichneumonidae)

Pimpla turionellae (Linnaeus) (Hymenoptera: Ichneumonidae)

Trichogramma minutum Riley (Hymenoptera: Trichogrammatidae)

Agathis pumila (Ratzeburg) (Hymenoptera: Braconidae)

Chrysocharis laricellae (Ratzeburg) (Hymenoptera: Eulophidae)

Cirrospilus pictus (Nees) (Hymenoptera: Eulophidae)

Diadegma laricinellum (Strobl) (Hymenoptera: Ichneumonidae)

Dicladocerus japonicus Yoshimoto (Hymenoptera: Eulophidae)

Dicladocerus westwoodii Westwood (Hymenoptera: Eulophidae)

Apanteles breviventris (Ratzeburg) (Hymenoptera: Braconidae)

Apanteles coleophorae Wilkinson (Hymenoptera: Braconidae)

Apanteles corvinus Reinhard (Hymenoptera: Braconidae)

Campoplex borealis (Zetterstedt) (Hymenoptera: Ichneumonidae)

Campoplex Gravenhorst (Hymenoptera: Ichneumonidae)

Achrysocharoides Girault (Hymenoptera: Eulophidae)

Apanteles californicus Muesebeck (Hymenoptera: Braconidae)

Copidosoma deceptor Miller (Hymenoptera: Encyrtidae)

Dicladocerus Westwood (Hymenoptera: Eulophidae)

Eriplatys ardeicollis (Wesmael) (Hymenoptera: Ichneumonidae)

Phaeogenes Wesmael (Hymenoptera: Ichneumonidae)

Pnigalio Schrank (Hymenoptera: Eulophidae)

Sympiesis Förster (Hymenoptera: Eulophidae)

Zagrammosoma Ashmead (Hymenoptera: Eulophidae)
Europe

Europe

Europe

North America

North America

Europe

Europe

Europe

Europe

Asia

Europe

Europe

North America

Europe

Europe

North America

Europe

Europe

Europe

Europe

Asia

Europe

Europe

Europe

Europe

Europe

Europe

North America

North America

North America

North America

Europe

North America

Europe

North America

North America 
Target

\begin{tabular}{l}
\hline Species \\
\hline Cydia strobilella (Linnaeus) \\
(Lepidotera: Tortricidae) \\
Dendroctonus rufipennis \\
$\quad$ Kirby \\
(Coleoptera: Curculionidae) \\
Diprion similis (Hartig)
\end{tabular}

(Hymenoptera: Diprionidae)

Eulecanium tiliae

(Linnaeus)

(Hemiptera: Coccidae)

Euproctis chrysorrhoea

(Linnaeus)

(Lepidoptera: Lymantriidae)

\section{Exoteleia pinifoliella}

Chambers

(Lepidoptera: Gelechiidae)

Fenusa pumila (LePeletier)

(Hymenoptera: Tenthredinidae)

Gilpinia frutetorum

(Fabricius)

(Hymenoptera: Diprionidae)

Gilpinia hercyniae (Hartig)

(Hymenoptera: Diprionidae)
Common nam

Spruce seed moth

Native range

Spruce beetle

Holarctic

North America

Introduced pine sawfly

Europe

Nut scale

Europe

Brown-tail moth

Europe

Pine needleminer

North America

Birch leafminer

Europe

Nursery Pine Sawfly

Europe
Agent

Species

Origin of collections

Ascogaster quadridentata Wesmael (Hymenoptera: Braconidae)

Macrocentrus ancylivorus Rohwer (Hymenoptera: Braconidae)

Rhizophagus Herbst (Coleoptera: Monotomidae)

Rhopalicus tutela (Walker) (Hymenoptera: Pteromalidae)

Monodontomerus dentipes (Dalman) (Hymenoptera: Torymidae)

Blastothrix sericea (Dalman) (Hymenoptera: Encyrtidae)

Encyrtus fuscus (Howard) (Hymenoptera: Encyrtidae)

Apanteles lacteicolor Viereck (Hymenoptera: Braconidae)

Calosoma sycophanta (Linnaeus) (Coleoptera: Carabidae)

Compsilura concinnata Meigen (Diptera: Tachinidae)

Meteorus versicolor (Wesmael) (Hymenoptera: Braconidae)

Achrysocharoides Girault (Hymenoptera: Eulophidae)

Apanteles californicus Muesebeck (Hymenoptera: Braconidae)

Zagrammosoma Ashmead (Hymenoptera: Eulophidae)

Grypocentrus albipes Ruthe (Hymenoptera: Ichneumonidae)

Lathrolestes nigricollis (Thomson) (Hymenoptera: Ichneumonidae)

Dahlbominus fuscipennis (Zetterstedt) (Hymenoptera: Eulophidae)

Drino inconspicua (Meigen) (Diptera: Tachinidae)

Exenterus abruptorius (Thunberg) (Hymenoptera: Ichneumonidae)

Exenterus amictorius (Panzer) (Hymenoptera: Ichneumonidae)

Exenterus confusus Kerrich (Hymenoptera: Ichneumonidae)

Pleolophus basizonus (Gravenhorst) (Hymenoptera: Ichneumonidae)

Closterocerus ruforum (Krausse) (Hymenoptera: Eulophidae)

Blondelia inclusa (Hartig) (Diptera: Tachinidae)

Dahlbominus fuscipennis (Zetterstedt) (Hymenoptera: Eulophidae)

Dipriocampe diprioni (Ferrière) (Hymenoptera: Eulophidae)

Drino bohemica Mesnil (Diptera: Tachinidae)

Drino inconspicua (Meigen) (Diptera: Tachinidae)

Drino" Robineau-Desvoidy (Diptera: Tachinidae)

Exenterus abruptorius (Thunberg) (Hymenoptera: Ichneumonidae)

Exenterus adspersus Hartig (Hymenoptera: Ichneumonidae) $)^{\mathbb{I}}$

Exenterus amictorius (Panzer) (Hymenoptera: Ichneumonidae)

Exenterus confusus Kerrich (Hymenoptera: Ichneumonidae)

Exenterus tricolor Roman (Hymenoptera: Ichneumonidae)

Exenterus vellicatus Cushman (Hymenoptera: Ichneumonidae)

Lamachus albopictus Cushman (Hymenoptera: Ichneumonidae)
North America

North America

Europe

Europe

Europe

Europe

North America

Europe

Europe

Europe

Europe

North America

North America

North America

Europe

Europe

Europe

Europe

Europe

Europe

Europe

Europe

Europe

Europe

Europe

Europe

Europe

Europe

Asia

Europe

Europe

Europe

Europe

Europe

Europe

Asia 
Table 1. Continued

Species

Target

Agent

Common name

Native range

Species

Origin of collections

Lamachus coalitorius (Thunberg) (Hymenoptera: Ichneumonidae)

Europe

Lamachus eques (Hartig) (Hymenoptera: Ichneumonidae)

Lamachus Förster (Hymenoptera: Ichneumonidae)

Lamachus Förster (Hymenoptera: Ichneumonidae)**

Lamachus Förster (Hymenoptera: Ichneumonidae) ${ }^{\dagger \dagger}$

Lophyroplectus oblongopunctatus (Hartig) (Hymenoptera:

Ichneumonidae)

Lophyroplectus Thomson (Hymenoptera: Ichneumonidae)

Mesopolobus subfumatus (Ratzeburg) (Hymenoptera: Pteromalidae) Europe

Monodontomerus japonicus Ashmead (Hymenoptera: Torymidae)

Olesicampe ratzeburgi (Tschek) (Hymenoptera: Ichneumonidae)

Pleolophus basizonus (Gravenhorst) (Hymenoptera: Ichneumonidae) Europe

(Hymenoptera: Tenthredinidae)

Lambdina fiscellaria

Striped alder sawfly

Hemlock looper

Guenée) ${ }^{+*}$

(Lepidoptera: Geometridae)

Lecanium Burmeister

(Hemiptera: Coccidae)

Leucoma salicis (Linnaeus)

(Lepidoptera: Lymantriidae)

Lymantria dispar dispar

(Linnaeus)

(Lepidoptera: Erebidae)

\section{Malacosoma disstria}

Hübner

(Lepidoptera: Lasiocampidae)

Mindarus abietinus Koch

(Hemiptera: Mindaridae)

Nematus ribesii (Scopoli)

(Hymenoptera: Tenthredinidae)

Satin moth
Drino bohemica Mesnil (Diptera: Tachinidae)

Holarctic

North America

North America

Winthemia occidentis Reinhard (Diptera: Tachinidae)

Calosoma sycophanta (Linnaeus) (Coleoptera: Carabidae)

North America

Palearctic

\section{Encyrtus fuscus (Howard) (Hymenoptera: Encyrtidae)}

Apanteles solitarius (Ratzeburg) (Hymenoptera: Braconidae) Compsilura concinnata (Meigen) (Diptera: Tachinidae)

Meteorus versicolor (Wesmael) (Hymenoptera: Braconidae)

Trichomalopsis hemiptera (Walker) (Hymenoptera: Pteromalidae)

Anastatus japonicus Ashmead (Hymenoptera: Eupelmidae)

Aphantorhaphopsis samarensis (Villeneuve) (Diptera: Tachinidae)

Cotesia melanoscela (Ratzeburg) (Hymenoptera: Braconidae)

Glyptapanteles flavicoxis (Marsh) (Hymenoptera: Braconidae)

Ooencyrtus kuvanae (Howard) (Hymenoptera: Encyrtidae)

Arachnidomyia aldrichi (Parker) (Diptera: Sarcophagidae)

Calosoma sycophanta (Linnaeus) (Coleoptera: Carabidae)

Compsilura concinnata Meigen (Diptera: Tachinidae)

Leschenaultia leucophrys (Wiedemann) (Diptera: Tachinidae)

Aphidoletes aphidimyza (Rondani) (Diptera: Cecidomyiidae)

Chrysoperla carnea (Stephens) Neuroptera: Chrysopidae)

Harmonia axyridis (Pallas) (Coleoptera: Coccinellidae)

Trichogramma minutum Riley (Hymenoptera: Trichogrammatidae)
Europe

Asia

Europe

Europe

Europe

Europe

North America

Europe

North America

Europe

Europe

Europe

Europe

Europe

Europe

Asia

Europe

Asia

North America

Europe

Europe

North America

North America

North America

Europe

North America 


$\frac{\text { Species }}{\text { Neodiprion abietis (Harris) }}$

Common name

Native range

Species

Origin of collections

(Hymenoptera: Diprionidae)

Neodiprion lecontei (Fitch)

(Hymenoptera: Diprionidae)

Balsam fir sawfly

North America

Redheaded pine sawfly North America

Drino bohemica Mesnil (Diptera: Tachinidae)

Closterocerus ruforum (Krausse) (Hymenoptera: Eulophidae) Dahlbominus fuscipennis (Zetterstedt) (Hymenoptera: Eulophidae) Dipriocampe diprioni (Ferrière) (Hymenoptera: Tetracampidae) Drino bohemica Mesnil (Diptera: Tachinidae)

Drino" Robineau-Desvoidy (Diptera: Tachinidae)

Exenterus abruptorius (Thunberg) (Hymenoptera: Ichneumonidae) Lophyroplectus oblongopunctatus (Hartig) (Hymenoptera:

Ichneumonidae)

Oresbius subguttatus (Gravenhorst) (Hymenoptera: Ichneumonidae) Pleolophus basizonus (Gravenhorst) (Hymenoptera: Ichneumonidae)

Neodiprion nanulus nanulus

Red pine sawfly

North America$$
\text { Schedl }
$$

(Hymenoptera: Diprionidae)

Neodiprion pratti banksinae

$$
\text { Rohwer }
$$

(Hymenoptera: Diprionidae)

Neodiprion sertifer (Geoffroy)

European pine sawfly

Europe

(Hymenoptera: Diprionidae)

Neodiprion swainei

$$
\text { Middleton }
$$

(Hymenoptera: Diprionidae)
Swaine jack pine sawfly North America
Dahlbominus fuscipennis (Zetterstedt) (Hymenoptera: Eulophidae)

Drino bohemica Mesnil (Diptera: Tachinidae)

Exenterus abruptorius (Thunberg) (Hymenoptera: Ichneumonidae) Exenterus amictorius (Panzer) (Hymenoptera: Ichneumonidae)

Dahlbominus fuscipennis (Zetterstedt) (Hymenoptera: Eulophidae)

Dipriocampe diprioni (Ferrière) (Hymenoptera: Tetracampidae)

Drino bohemica Mesnil (Diptera: Tachinidae)

Exenterus amictorius (Panzer) (Hymenoptera: Ichneumonidae)

Exenterus confusus Kerrich (Hymenoptera: Ichneumonidae)

Agrothereutes abbreviatus (Fabricius) (Hymenoptera:

Ichneumonidae)

Closterocerus formosus Westwood (Hymenoptera: Eulophidae)

Closterocerus ruforum (Krausse) (Hymenoptera: Eulophidae)

Dahlbominus fuscipennis (Zetterstedt) (Hymenoptera: Eulophidae)

Dipriocampe diprioni (Ferrière) (Hymenoptera: Tetracampidae)

Drino bohemica Mesnil (Diptera: Tachinidae)

Exenterus abruptorius (Thunberg) (Hymenoptera: Ichneumonidae)

Exenterus amictorius (Panzer) (Hymenoptera: Ichneumonidae)

Lamachus eques (Hartig) (Hymenoptera: Ichneumonidae)

Lophyroplectus oblongopunctatus (Hartig) (Hymenoptera:

Ichneumonidae)

Pleolophus basizonus (Gravenhorst) (Hymenoptera: Ichneumonidae)

Drino bohemica Mesnil (Diptera: Tachinidae)

Formica lugubris Zetterstedt (Hymenoptera: Formicidae)

Formica obscuripes Forel (Hymenoptera: Formicidae)

Pleolophus basizonus (Gravenhorst) (Hymenoptera: Ichneumonidae)

Europe

Europe

Europe

Europe

Europe

Asia

Europe

Europe

Europe

Europe

Europe

Europe

Europe

Europe

Europe

Europe

Europe

Europe

Europe

Europe

Europe

Europe

Europe

Europe

Europe

Europe

Europe

Europe

Europe

Europe

Europe

Europe

North America

Europe 
Target

\begin{tabular}{l} 
Species \\
\hline Neodiprion tsugae \\
Middleton \\
(Hymenoptera: Diprionidae) \\
Neodiprion virginianus
\end{tabular}

Neodiprion virginianus

complex

(Hymenoptera: Diprionidae)

Operophtera brumata

Linnaeus

(Lepidoptera: Geometridae)

\section{Pikonema alaskensis}

\section{(Rohwer)}

(Hymenoptera: Tenthredinidae)

Pineus strobi (Hartig)

(Hemiptera: Adelgidae)

Pissodes strobi (Peck)

(Coleoptera: Curculionidae)

Pristiphora erichsonii

(Hartig)

(Hymenoptera: Tenthredinidae)

\section{Pristiphora geniculata} (Hartig)

(Hymenoptera: Tenthredinidae)

\section{Common name}

Hemlock sawfly

Red-headed jack pine sawfly

Winter moth

Europe

Yellowheaded spruce sawfly

Pine bark adelgid

White pine weevil

Larch sawfly 
Target

\section{Species}

Profenusa thomsoni (Konow)

(Hymenoptera: Tenthredinidae)

Rhyacionia buoliana

(Denis and Schiffermüller)

(Lepidoptera: Tortricidae)

Common name

Ambermarked birch

leafminer

European pine shoot$$
\text { moth }
$$

Europe

Europe
Agent

Species

Origin of collections

Lathrolestes thomsoni Reshchikov (Hymenoptera: Ichneumonidae) North America

Actia interrupta Curran (Diptera: Tachinidae)

Europe

Baryscapus turionum (Hartig) (Hymenoptera: Eulophidae)

Bassus binominatus (Muesebeck) (Hymenoptera: Braconidae)

Campoplex difformis (Gmelin) (Hymenoptera: Ichneumonidae)

Copidosoma filicorne (Dalman) (Hymenoptera: Encyrtidae)

Exeristes roborator (Fabricius) (Hymenoptera: Ichneumonidae)

Exeristes ruficollis (Gravenhorst) (Hymenoptera: Ichneumonidae)

Goniozus nigrifemur (Ashmead) (Hymenoptera: Bethylidae)

Lypha dubia (Fallén) (Diptera: Tachinidae)

Orgilus obscurator (Nees) (Hymenoptera: Ichneumonidae)

Pimpla turionellae (Linnaeus) (Hymenoptera: Ichneumonidae)

Pristomerus Curtis (Hymenoptera: Ichneumonidae)

Scambus buolianae (Hartig) (Hymenoptera: Ichneumonidae)

Scambus sagax (Hartig) (Hymenoptera: Ichneumonidae)

Sinophorus turionum (Ratzeburg) (Hymenoptera: Ichneumonidae)

Temelucha interruptor (Gravenhorst) (Hymenoptera: Ichneumonidae)

Trichogramma minutum Riley (Hymenoptera: Trichogrammatidae)
Europe

North America

Europe

Europe

Europe

Europe

South America

Europe

Europe

Europe

Europe

Europe

Europe

Europe

Europe

North America

Mutuura and Freeman

(Lepidoptera: Tortricidae)

References: McLeod et al. (1962), Reeks and Cameron (1971), Beirne and Kelleher (1973), Kelleher and Hulme (1984), Mason and Huber (2002), Mason and Gillespie (2013), Roscoe et al. (2015).

* = Neocnemodon Goffe, likely two species released: Cnemondon latitarsus Egger and C. pubescens Delucchi and Pschorn-Walcher

= Pullus Mulsant

D.B.L., personal observation

${ }^{\S}$ Given the host, the target was likely juniper scale $C$. juniperi (Bouché) not $C$. visci.

"Two species were released, one subsequently identified as Drino gilva (Hartig)

"I Later determined to be a species complex, all agents released under this name.

** Listed as species "Number 1" in McLeod et al. (1962)

${ }^{\dagger \dagger}$ Listed as species "Number 72" in McLeod et al. (1962)

${ }^{\dagger}$ Formerly recognised as two subspecies L. f. fiscellaria (hemlock looper) and L. f. somniaria (Hulst) (oak looper) (Sperling et al.1999), C. sycophanta was released against L. fiscellaria feeding on oak, see text for discussion.

${ }_{\S}$ Early releases were likely made against native North American populations, later releases likely targeted introduced European populations, see text for discussion. 
Fig. 1. The number of native and non-native forest insect species targeted for biological control in Canada between the 1890s and 2000s.

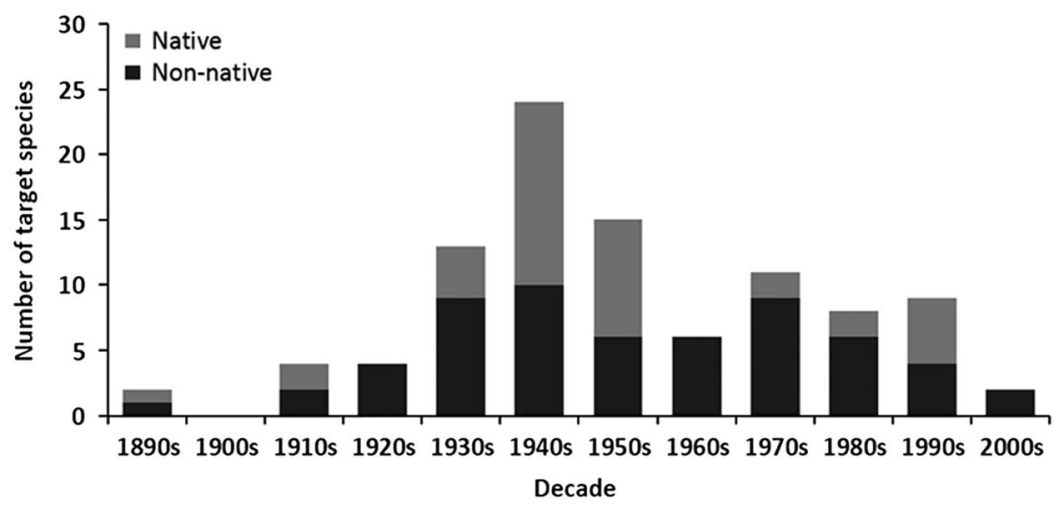

Fig. 2. The number of parasitoid and predator agents released in biological control programmes in Canadian forests between the 1890s and 2000s.

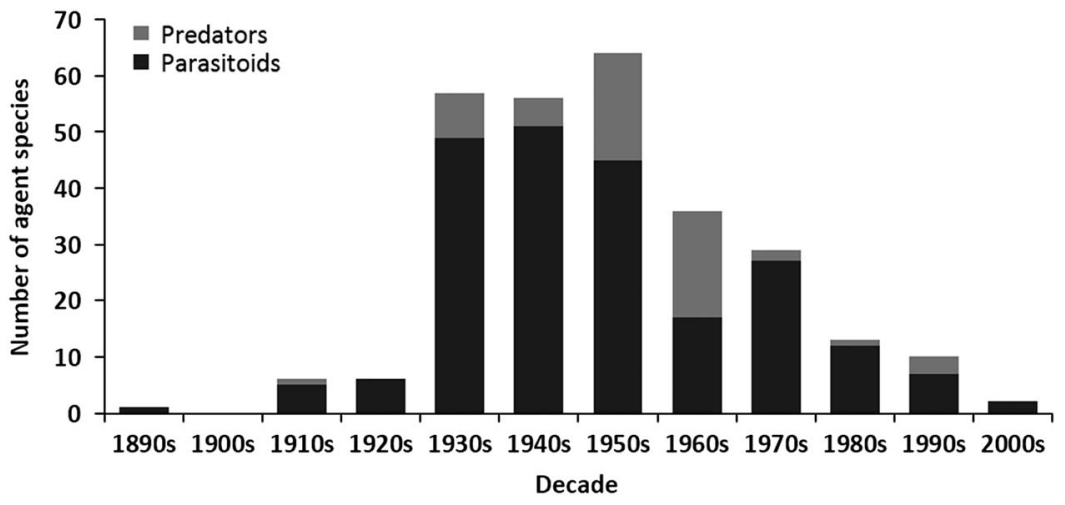

Table 2. Number of native and non-native forest insect species in each major order targeted for biological control, and the number of native and non-native insect parasitoids and predators released in Canadian forests.

\begin{tabular}{|c|c|c|c|c|c|c|}
\hline \multirow[b]{2}{*}{ Order } & \multicolumn{3}{|c|}{ Targets } & \multicolumn{3}{|c|}{ Agents } \\
\hline & Native & Non-native & Total & Native & Non-native & Total \\
\hline Coleoptera & 2 & 0 & 2 & 0 & 16 & 16 \\
\hline Diptera & - & - & - & 11 & 22 & 33 \\
\hline Hemiptera & 3 & 3 & 6 & 0 & 2 & 2 \\
\hline Hymenoptera & 10 & 9 & 19 & 18 & 86 & 104 \\
\hline Lepidoptera & 7 & 7 & 14 & - & - & - \\
\hline Neuroptera & - & - & - & 1 & 2 & 3 \\
\hline
\end{tabular}

species (Table 2; Fig. 3), dominating every decade except the 1910s, 1940s, and 1950s when they represented about half (Fig. 1). Like the species they target, most agents $(n=104)$ have originated from Europe, followed by North America $(n=32)$, and then Asia $(n=23)$ (Table 1; Fig. 3). While agents have also come from Australia $(n=1)$ and South America 
Fig. 3. Geographic origin of biological control targets and agents in Canadian forests. Circles are scaled to relative abundance of species.

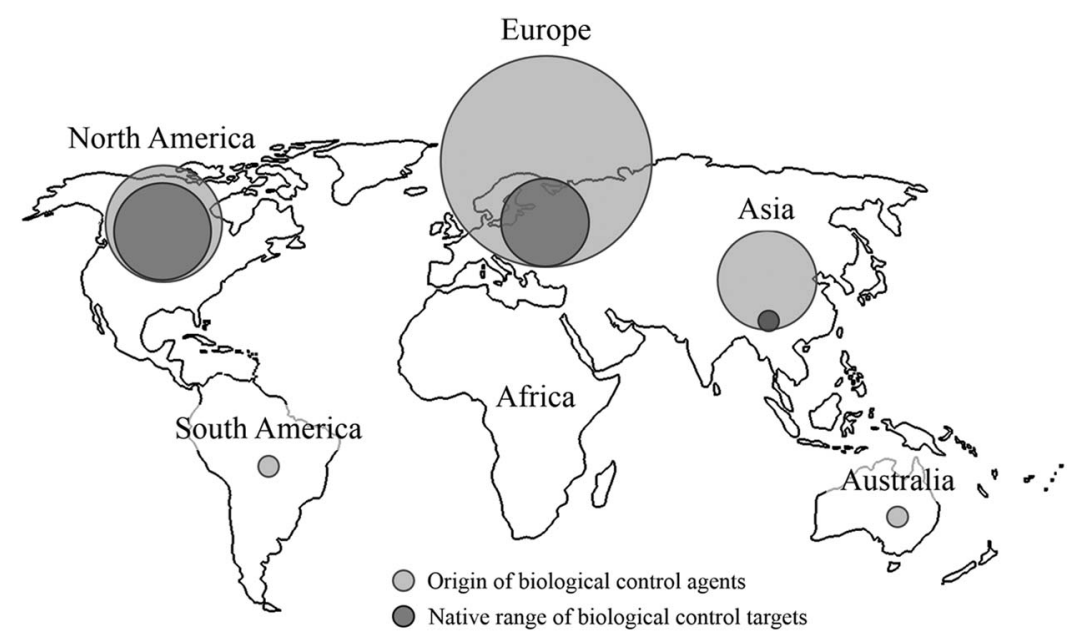

( $n=1)$, none of these have established (Kelleher and Hulme 1984). The dominance of European agents in this timeline reflects their use in classical biological control programmes, those aimed at non-native European targets in Canada (Fig. 3). Indeed, over $90 \%(149 / 161)$ of the Canadian biological control programmes in forests fit this definition of introduction biological control, and more specifically classical biological control (130/161). The few exceptions include; the non-native ambermarked birch leafminer, Profenusa thomsoni (Konow) (Hymenoptera: Tenthredinidae), controlled by the native parasitoid, Lathrolestes thomsoni Reschikov (Hymenoptera: Ichneumonidae) (MacQuarrie et al. 2013a), and the native Swaine jack pine sawfly, Neodiprion swainei Middleton (Hymenoptera: Diprionidae), suppressed by the non-native parasitoid, $P$. basizonus (Price and Tripp 1972). The only instance of a native agent targeting a native species is through inundative release and augmentation of the native egg parasitoid, T. minutum against the native spruce budworm, Choristoneura fumiferana (Clemens) (Lepidoptera: Tortricidae), and the native spruce bud moth, Zeiraphera canadensis Mutuura and Freeman (Lepidoptera: Tortricidae) (Smith et al. 1990; West et al. 2002b).

The use of native agents in biological control programmes across Canadian forests merits some interpretation. Twelve of the 32 of the native agents used have been for augmentation biological control (either intentional or unintentional), and were already present in the area where they were released. For instance, two parasitoids of larch sawfly, Bessa harveyi (Townsend) (Diptera: Tachinidae) and Tritneptis klugii (Ratzenburg) (Hymenoptera: Pteromalidae), were both widely redistributed within Canada before they were found to be native North American species (McGugan and Coppel 1962). Of the other native agents, 19 were simply relocated within North America to locations where the target was present but the agent was absent.

The number of successful biological control programmes in Canada has never been established conclusively, as "success" often depends on the goal and strategy used (e.g., introduction, augmentation, or conservation biological control). Previous estimates of success, based primarily on introduction or inoculative augmentation programmes, have tallied successful control against either five (Beirne 1975), seven (Munroe 1971; Hulme 1988), or nine (Wallace 1995) targets. However, these authors differed slightly in their criteria for "success". Most agreed that success should include target suppression (Hulme 1988; Wallace 1995), but establishment was also important for introduction and inoculative augmentation, unlike inundative augmentation releases. Here, we assessed the programmes listed in Table 1 and defined success as either: (1) the agent became 
established in the target's range and caused a measurable contribution to the control of the target (e.g., reduced the pest below an economic threshold) or (2) the agent provided at least local and measurable control of the target by the released agent but failed to achieve long-term control (as in the case of inundative augmentation releases).

Using these two categories of success, we found that: 15 agents successfully controlled nine targets, with some agents controlling multiple targets (Table 3; Section A); and an additional seven agents had an important impact on six more targets, albeit with no long-term control (Table 3; Section B). Among the influential agents, Compsilura concinnata (Meigen) (Diptera: Tachinidae) was the only one to suppress two targets; the non-native browntail moth, Euproctis chrysorrhoea (Linnaeus) (Lepidoptera: Lymantriidae), and the satin moth, although it also influenced the control of the non-native European gypsy moth, Lymantria dispar dispar (Linnaeus) (Lepidoptera: Erebidae).

\section{Four eras of biological control in Canada}

The history of biological control programmes in Canadian forests can be divided into four broad eras, each defined by different factors affecting the strategies for forest pest management. Due to the large number of projects over this time (Table 1), we can only highlight the most influential projects or those that have demonstrated novel aspects in biological control development and practice. More detail on individual projects can be found in a sequential series of review monographs (McGugan and Coppel 1962; Reeks and Cameron 1971; Kelleher and Hulme 1984; Mason and Huber 2002; Mason and Gillespie 2013), and a review by Armstrong and Ives (1995). The history of the people and institutions responsible for biological control programmes in Canada have been also documented by Glen (1956), Beirne (1973, 1975), Beirne and Kelleher (1973), Riegert (1980), Richmond (1983), and Quiring et al. (2015).

\section{The early era: 1882-1945}

One of the earliest introductions against a tree pest in Canada was a parasitoid of the non-native European fruit lecanium, Parthenolecanium corni (Bouché) (Hemiptera: Coccidae), introduced from
California, United States of America in 1896 to control an outbreak of a species of lecanium scale, Parthenolecanium Šulc, on elm, Ulmus (Ulmaceae), near Ottawa, Ontario, Canada (Beirne and Kelleher 1973). As in 1882, with the first introduction against currantworm, neither was considered successful, likely because both agents were already present in Canada and the introductions provided no additional mortality (Beirne and Kelleher 1973). Interestingly, the releases against currantworm and lecanium scale represent the first time insects were shipped between two countries for the purposes of biological control in North America, and the first to be tried in Canada (Simmonds et al. 1976). Surprisingly, it would take until 1910 before the permanent establishment of an introduced biological control agent in Canada could be shown.

Serious work on Canadian biological control of forest insects began in 1909 with the appointment of C. Gordon Hewitt as Dominion Entomologist. Since the 1880s, occasional outbreaks of the larch sawfly had occurred throughout eastern Canada, and Hewitt arrived in the middle of one. Immediately, he initiated a biological control programme against the sawfly aimed at importing Mesoleius tenthredinis Morley (Hymenoptera: Ichneumonidae), its natural enemy in the United Kingdom (Hewitt 1912). Between 1910 and 1913, sawfly cocoons parasitised in the United Kingdom were shipped to Canada and set out in infested stands across Ontario, Québec, and Manitoba. Unfortunately, failure to screen the released material resulted in several species of parasitoids being introduced (McGugan and Coppel 1962), along with a new European strain of the larch sawfly itself (Wong 1974; Ives and Muldrew 1984); this would have important consequences for later biological control efforts (see The intensive era: 1945-1970). By 1919, the programme was considered successful in reducing sawfly populations; for the first time, this established biological control as a viable tactic to manage forest pests in Canada (Turnbull and Chant 1961).

Hewitt influenced later work by J.D. Tothill, who introduced at least three parasitoids and a predator into the Maritime provinces against the browntail moth around 1914 (Table 1) (Beirne 1973). Tothill made a series of introductions against both the browntail moth and the 
Table 3. Biological control agent species (A) successfully controlling their target species or (B) providing local and measurable short-term control of their target in biological control programmes against forest insects in Canada. See Table 1 for origin of agents and targets.

\begin{tabular}{|c|c|c|}
\hline Target species & Common name & Agent species \\
\hline \multicolumn{3}{|c|}{ (A) Biological control agent species successfully established and controlling their target } \\
\hline $\begin{array}{l}\text { Coleophora laricella (Hübner) } \\
\text { (Lepidoptera: Coleophoridae) }\end{array}$ & Larch casebearer & $\begin{array}{l}\text { Agathis pumila (Ratzeburg) } \\
\text { (Hymenoptera: Braconidae) } \\
\text { Epilampsis laricinellae (Ratzeburg) } \\
\text { (Hymenoptera: Eulophidae) }\end{array}$ \\
\hline $\begin{array}{l}\text { Euproctis chrysorrhoea (Linnaeus) } \\
\text { (Lepidoptera: Lymantriidae) }\end{array}$ & Browntail moth & $\begin{array}{l}\text { Compsilura concinnata (Meigen) } \\
\text { (Diptera: Tachinidae) }\end{array}$ \\
\hline $\begin{array}{l}\text { Gilpinia hercyniae (Hartig) } \\
\text { (Hymenoptera: Diprionidae) }\end{array}$ & $\begin{array}{l}\text { European spruce } \\
\text { sawfly }\end{array}$ & $\begin{array}{l}\text { Dahlbominus fuscipennis (Zetterstedt) } \\
\quad \text { (Hymenoptera: Eulophidae) } \\
\text { Drino bohemica } \text { Mesnil (Diptera: Tachinidae) } \\
\text { Exenterus vellicatus } \text { Cushman } \\
\quad \text { (Hymenoptera: Ichneumonidae) }\end{array}$ \\
\hline $\begin{array}{l}\text { Leucoma salicis (Linnaeus) } \\
\text { (Lepidoptera: Lymantriidae) }\end{array}$ & Satin moth & $\begin{array}{l}\text { Apanteles solitarius } \text { (Ratzeburg) } \\
\text { (Hymenoptera: Braconidae) } \\
\text { Compsilura concinnata } \text { (Meigen) } \\
\text { (Diptera: Tachinidae) } \\
\text { Meteorus versicolor } \text { (Wesmael) } \\
\text { (Hymenoptera: Braconidae) }\end{array}$ \\
\hline $\begin{array}{l}\text { Neodiprion sertifer (Geoffroy) } \\
\text { (Hymenoptera: Diprionidae) }\end{array}$ & $\begin{array}{l}\text { European pine } \\
\text { sawfly }\end{array}$ & $\begin{array}{l}\text { Dahlbominus fuscipennis (Zetterstedt) } \\
\text { (Hymenoptera: Eulophidae) } \\
\text { Pleolophus basizonus (Gravenhorst) } \\
\text { (Hymenoptera: Ichneumonidae) }\end{array}$ \\
\hline $\begin{array}{l}\text { Operophtera brumata (Linnaeus) } \\
\text { (Lepidoptera: Geometridae) }\end{array}$ & Winter moth & $\begin{array}{l}\text { Agrypon flaveolatum (Gravenhorst) } \\
\text { (Hymenoptera: Ichneumonidae) } \\
\text { Cyzenis albicans (Fallén) (Diptera: Tachinidae) }\end{array}$ \\
\hline $\begin{array}{l}\text { Pristiphora erichsonii (Hartig) } \\
\text { (Hymenoptera: Tenthredinidae) }\end{array}$ & Larch sawfly & $\begin{array}{l}\text { Mesoleius tenthredinis Morley } \\
\text { (Hymenoptera: Ichneumonidae) } \\
\text { Olesicampe benefactor Hinz } \\
\text { (Hymenoptera: Ichneumonidae) }\end{array}$ \\
\hline $\begin{array}{l}\text { Pristiphora geniculata (Hartig) } \\
\text { (Hymenoptera: Tenthredinidae) }\end{array}$ & $\begin{array}{l}\text { Mountain ash } \\
\text { sawfly }\end{array}$ & $\begin{array}{l}\text { Olesicampe geniculatae Quedenau and Lim } \\
\text { (Hymenoptera: Ichneumonidae) }\end{array}$ \\
\hline $\begin{array}{l}\text { Rhyacionia buoliana (Denis and } \\
\text { Schiffermüller) }\end{array}$ & $\begin{array}{l}\text { European pine } \\
\text { shoot moth }\end{array}$ & $\begin{array}{l}\text { Orgilus obscurator } \text { (Nees) } \\
\quad \text { (Hymenoptera: Braconidae) }\end{array}$ \\
\hline
\end{tabular}

(B) Biological control agent species providing local and measurable short-term control of their target

\begin{tabular}{|c|c|c|}
\hline $\begin{array}{l}\text { Adelges piceae (Ratzeburg) } \\
\text { (Hemiptera: Adelgidae) }\end{array}$ & $\begin{array}{l}\text { Balsam woolly } \\
\text { aphid }\end{array}$ & $\begin{array}{l}\text { Laricobius erichsonii Rosenhauer } \\
\text { (Coleoptera: Derodontidae) }\end{array}$ \\
\hline $\begin{array}{l}\text { Choristoneura fumiferana } \\
\text { (Clemens) (Lepidoptera: Tortricidae) }\end{array}$ & Spruce budworm & $\begin{array}{l}\text { Trichogramma minutum Riley } \\
\text { (Hymenoptera: Trichogrammatidae) }\end{array}$ \\
\hline $\begin{array}{l}\text { Diprion similis (Hartig) } \\
\text { (Hymenoptera: Diprionidae) }\end{array}$ & $\begin{array}{l}\text { Introduced pine } \\
\text { sawfly }\end{array}$ & $\begin{array}{l}\text { Monodontomerus dentipes (Dalman) } \\
\text { (Hymenoptera: Torymidae) }\end{array}$ \\
\hline $\begin{array}{l}\text { Eulecanium tiliae (Linnaeus) } \\
\text { (Hemiptera: Coccidae) }\end{array}$ & Lecanium scale & $\begin{array}{l}\text { Blastothrix sericeae (Dalman) } \\
\text { (Hymenoptera: Encyrtidae) }\end{array}$ \\
\hline $\begin{array}{l}\text { Fenusa pumila (LePeletier) } \\
\text { (Hymenoptera: Tenthredinidae) }\end{array}$ & Birch leafminer & $\begin{array}{l}\text { Lathrolestes nigricollis (Thomson) } \\
\text { (Hymenoptera: Ichneumonidae) }\end{array}$ \\
\hline $\begin{array}{l}\text { Neodiprion swanei Middleton } \\
\text { (Hymenoptera: Diprionidae) }\end{array}$ & $\begin{array}{l}\text { Swaine jack pine } \\
\text { sawfly }\end{array}$ & $\begin{array}{c}\text { Pleolophus basizonus (Gravenhorst) } \\
\text { (Hymenoptera: Ichneumonidae) }\end{array}$ \\
\hline $\begin{array}{l}\text { Profenusa thomsoni (Konow) } \\
\text { (Hymenoptera: Tenthredinidae) }\end{array}$ & $\begin{array}{l}\text { Ambermarked birch } \\
\text { leafminer }\end{array}$ & $\begin{array}{l}\text { Lathrolestes thomsoni Reschikov } \\
\text { (Hymenoptera: Ichneumonidae) }\end{array}$ \\
\hline
\end{tabular}


European gypsy moth by relocating parasitised larvae from New England (United States of America) into eastern Canada, including a number into Ontario and Québec (neither of which apparently became established) (McGugan and Coppel 1962). Tothill's intent was to get agents established on native species of Lepidoptera before the actual targets arrived. However, the effect of this anticipatory biological control effort was never examined. His introductions into the Maritime provinces coincided with a decline in the browntail moth but were considered a failure because no direct link could be made between the introductions and the decline of the target (Turnbull and Chant 1961; Beirne and Kelleher 1973). Tothill later expanded his work by introducing Calosoma sycophanta (Linnaeus) (Coleoptera: Carabidae), a non-native predator of European gypsy moth, into British Columbia, Canada as an agent against the native hemlock looper. This was the first attempt in Canada to create a "new association" between a non-native agent and a native insect. Here again, the actual introduction was considered successful but not effective, as C. synchophanta failed to control its target (Munroe 1971). Subsequent work has shown that $C$. concinnata, likely introduced to Canada during these early Tothill releases, is one of the main causes for collapse of browntail moth populations across eastern North America (Elkinton and Boettner 2012).

The initiatives of Hewitt and Tothill greatly accelerated biological control in Canada, launching programmes against at least 12 targets between 1925 and 1940 (McGugan and Coppel 1962) (Fig. 1). Beirne (1973) suggested that this activity was precipitated by the successful control of cottony cushion scale in the United States of America, the larch sawfly and browntail moth in Canada, and similar successes in the suppression of agricultural insect pests (see McLeod et al. 1962). Some of the projects launched during this time continued for decades, one of the best examples being the non-native European pine sawfly, Neodiprion sertifer (Geoffroy) (Hymenoptera: Diprionidae), which had agents released against it in Canada for over 40 years (Griffiths et al. 1984). The success of biological control in Canadian forestry (and similar successes in Canadian agriculture) demonstrated its value and highlighted the need for a dedicated biological control organisation in Canada. As a result, in 1915 the first biological control laboratory was established at Fredericton, New Brunswick, moving eventually to Belleville, Ontario in 1928 where it became known as the Dominion Parasite Laboratory, and later the Entomology Research Institute (Glen 1956; Beirne 1973). The work done at the Belleville laboratories would support most of the biological control programmes in Canada until their closure in 1972.

The non-native European spruce sawfly, Gilpinia hercyniae (Hartig) (Hymenoptera: Diprionidae), dominated forest insect problems in Canada during the 1930s (Glen 1956), and programmes for its control exemplified biological control before World War II. This non-native sawfly was first reported in the Gaspé region of Québec in 1933, likely introduced from Europe, and provided an ideal opportunity for research. Unfortunately, early work showed that the sawfly was rare in Europe and that there were two additional congeneric species with similar morphology and ecology; Gilpinia polytoma (Hartig) and G. frutetorum (Fabricius). This led to the search for agents across a wide range of target species, including related genera within the Diprionidae (i.e., Gilpinia Benson, Diprion Schrank, and Neodiprion Rohwer) and other sawflies on spruce (Picea Miller; Pinaceae). In the end, 220 potential agent species were identified, imported to the laboratories in Belleville, reared, and many released into Canadian forests (Table 1; Glen 1956; McGugan and Coppel 1962; Reeks and Cameron 1971). By the end of the project, over 843 million individuals were released, with another 247 million released in the United States of America (Dowden 1962; McGugan and Coppel 1962). Despite this massive effort, classical biological control agents were not responsible for the eventual decline of the European spruce sawfly, but instead it was attributed to a nucleopolyhedralvirus, GhNPV (formerly Borrelinavirus hercyniae), brought in with agents during the 1930s (Bird and Elgee 1957). This virus spread quickly to wild European spruce sawfly populations causing significant mortality (Bird and Elgee 1957), and resulted in a shift in biological control work to mass-production of GhNPV (reviewed by van Frankenhuyzen et al. 2015). The virus became so successful that by 1943, classical biological control was scaled back to only production 
and release of a few agents. Complete suppression of the sawfly was achieved by the late 1940s and Canadian forests have not experienced a significant outbreak of this species since (Magasi and Syme 1984).

Classical biological control efforts against the European spruce sawfly clearly contributed to its long-term suppression even though most work pointed to GhNPV. Subsequent research showed that at low sawfly densities the virus was actually ineffective (Neilson and Morris 1964), and suppression was due to native predators and two non-native agents, Drino bohemica Mesnii (Diptera: Tachinidae) and Exenterus vellicatus (Cushman) (Hymenoptera: Ichneumonidae) (Neilson et al. 1971). The complexity of this density-dependent relationship was revealed during the 1970s when the application of insecticides for control of the spruce budworm in New Brunswick led to sawfly outbreaks. Research showed that these insecticides caused local extirpation of agents attacking the sawfly (including GhNPV), and that this enabled sawfly populations to rebound unchecked until the agents could re-establish and dampen the rise (Magasi and Syme 1984). Oddly, in the United States of America, Dowden (1962) attributed the control of high European spruce sawfly populations to two different parasitoids, D. fuscipennis and E. amictorius, a phenomenon that was not seen in Canada. To date, this difference has not been investigated.

\section{The intensive era: 1945-1970}

After 1945, biological control in Canadian forests shifted away from targets in coniferous forests, and forest pest management programmes became more reliant on synthesised insecticides (Glen 1956; Beirne 1973). At the same time, there was a tendency for biological control targets to have more cryptic life histories (i.e., inside plant tissues such as phloem) since this attribute made them more difficult to control. There was also greater recognition during this era that host range testing could be used to improve the selection of potential release agents, and thus have more impact against the target. Finally, concepts from the expanding field of animal ecology during this period (e.g., Holling 1959) started to filter into biological control, and greater emphasis was placed on the role of forest insect population dynamics in choosing targets and refining the selection process for agents.

The infrastructure and production of agents that supported the European spruce sawfly project during the 1930s influenced the direction of work against other targets during this era well into the late 1940s. This was due in part to World War II, which made new agents difficult to obtain from Europe (i.e., the native range of most targets during this period), and reduced the number of personnel available to work on biological control. These factors also led to a general pause in forest biological control until 1947, after which, Canada saw eight programmes launched within only three years. Despite this apparent returning interest, many of these programmes were only viable because agents produced by the Belleville laboratory for control of the European spruce sawfly became redundant following the success of the GhNPV (Table 4). As a consequence, the new introduction programmes tended to target species of minor importance, with some attempting classical biological control (targeted at the original non-native agent in Canada), while others sought to create "new associations", usually native targets (Tables 1 and 4). In general, these were small efforts and were not successful (Munroe 1971), although a number of native species were colonised that were not the target of any programme (Table 4). Somewhat surprisingly, there was little concern expressed at the time for the potential impact of these agents on non-target species, perhaps because some were considered pests as well.

Major programmes during this post-war period continued those begun before 1939. For example, work against the balsam woolly adelgid that had started in 1933 eventually led to the introduction of 13 generalist predators (Table 1), eight of which established (McGugan and Coppel 1962). These agents continued to be released in Newfoundland, British Columbia, and throughout the Maritimes during the 1960s, ending only in the early 1970s when it became apparent that they were ineffective against the adelgid (Clark et al. 1971; Schooley et al. 1984). Introductions against the European pine sawfly also continued during this time, again as an offshoot of the European spruce sawfly programme. Interestingly, agents 
Table 4. Parasitoid agents released in Canada for the control of European spruce sawfly, Gilpinia hercyniae (Hartig), 1933-1951, which were also released against other native and non-native targets.

\begin{tabular}{|c|c|c|c|}
\hline Agent & Native host(s) & Also released against & Recovered from \\
\hline \multicolumn{4}{|l|}{ Diptera: Tachinidae } \\
\hline Blondelia inclusa (Hartig) & $\begin{array}{l}\text { Lepidoptera, but reared from } \\
\text { sawfly cocoons }\end{array}$ & & Not recovered \\
\hline Drino bohemica Mesnil & $\begin{array}{l}\text { various Lepidoptera and sawfly } \\
\text { hosts including } G . \text { hercyinae }\end{array}$ & $\begin{array}{l}\text { Gilpinia frutetorum (Fabricus), Neodiprion } \\
\text { abietis (Harris), Neodiprion lecontei (Fitch), } \\
\text { Neodiprion pratti banksianae Rohwr, } \\
\text { Neodiprion sertifer (Geoffroy), Neodiprion } \\
\text { swainei Middleton, Neodiprion tsugae } \\
\text { Middleton, Pikonema alaskensis (Rohwer) }\end{array}$ & $\begin{array}{l}\text { Croesus latitarsus (Norton), G. hercyinae, } \\
\text { N. abietis complex, Neodiprion nanulus } \\
\text { Schedl, N. p. banksianae, Neodiprion pratti } \\
\text { paradoxicus Ross, Neodiprion virginianus } \\
\text { complex, P. alaskensis, Pikonema dimmokii } \\
\text { (Cresson) }\end{array}$ \\
\hline Drino Robineau-Desvoidy & Diprion nipponicus Rohwer & N. lecontei & Not recovered \\
\hline \multicolumn{4}{|l|}{ Hymenoptera: Eulophidae } \\
\hline $\begin{array}{l}\text { Closterocerus ruforum } \\
\text { (Krausse) }\end{array}$ & N. sertifer & N. lecontei, N. sertifer & Not recovered \\
\hline $\begin{array}{l}\text { Dahlbominus fuscipennis } \\
\text { (Zetterstedt) }\end{array}$ & $\begin{array}{l}\text { N. sertifer, Diprion pini Linnaeus, } \\
\text { Diprion similis (Hartig), } \\
\text { G. frutetorum, G. hercyniae }\end{array}$ & $\begin{array}{l}\text { G. frutetorum, N. lecontei, Neodiprion nanulus } \\
\text { nanulus Schedl, N. p. banksianae, N. sertifer, } \\
\text { N. tsugae }\end{array}$ & $\begin{array}{l}\text { Coleophora laricella (Hübner), G. frutetorum, } \\
\text { G. hercyniae, Glypta fumiferanae (Viereck), } \\
\text { N. n. nanulus, Neodiprion pinetum (Norton), } \\
\text { N. p. banksianae, N. sertifer, N. swainei }\end{array}$ \\
\hline $\begin{array}{l}\text { Dipriocampe diprioni } \\
\text { (Ferrière) }\end{array}$ & N. sertifer & N. lecontei, N. p. banksianae, N. sertifer & Not recovered \\
\hline \multicolumn{4}{|l|}{ Hymenoptera: Ichneumonidae } \\
\hline $\begin{array}{l}\text { Pleolophus basizonus } \\
\text { (Gravenhorst) }\end{array}$ & $\begin{array}{l}\text { diprionid sawflies, most from } \\
\text { N.sertifer and } D \text {. similis }\end{array}$ & $\begin{array}{l}\text { G. frutetorum, } N . \text { lecontei, } N \text {. sertifer, } \\
\text { N. swainei, } N . \text { virginianus complex }\end{array}$ & G. hercyniae, N. sertifer \\
\hline $\begin{array}{l}\text { Oresbius subguttatus } \\
\text { (Gravenhorst) }\end{array}$ & D. similis, $N$. sertifer & N. lecontei & G. hercyniae \\
\hline $\begin{array}{l}\text { Exenterus abruptorius } \\
\text { (Thunberg) }\end{array}$ & D. pini, N. sertifer & $\begin{array}{l}\text { G. frutetorum, N. lecontei, } N . \text { n. nanulus, } \\
\text { N. sertifer }\end{array}$ & $\begin{array}{l}\text { G. hercyniae, N. lecontei, N. p. banksianae, } \\
\text { N. sertifer, N. swainei }\end{array}$ \\
\hline Exenterus adsperus complex & G. hercyniae & & G. hercyniae \\
\hline Exenterus amictorius (Panzer) & G. hercyniae & $\begin{array}{l}\text { G. frutetorum, N. n. nanulus, N. p. banksianae, } \\
\text { N. sertifer }\end{array}$ & $\begin{array}{l}\text { D. similis, G. hercyniae, } N . \text { lecontei, } \\
\text { N. n. nanulus, } N \text {. sertifer, N. swainei, } \\
\text { N. virginianus complex }\end{array}$ \\
\hline Exenterus confusus Kerrich & G. hercyniae & G. frutetorum, N. p. banksianae & $\begin{array}{l}\text { G. hercyniae, } N . \text { abietis, } N . n . \text { nanulus } \\
\text { G. hercyniae, N. abietis }\end{array}$ \\
\hline
\end{tabular}

Drino Robineau-Desvoidy enoptera: Eulophidae

(Krausse)

ahlbominus fuscipennis

(Zetterstedt)

Dipriocampe diprioni

Pleolophus basizonus

Gravenhorst)

(Gravenhorst)

xenterus abruptorius

Exenterus adsperus complex

G. hercyniae

arious Lepidoptera and sawfly

hosts including $G$. hercyinae

Neodiprion pratti banksianae Rohwr,

(iprion sertifer (Geoffroy), Neodiprion

Middleton, Pikonema alaskensis (Rohwer)

lecontei, N. sertifer

frutetorum, N. lecontei, Neodiprion nanulus nanulus Schedl, N. p. banksianae, N. sertifer

. lecontei, N. p. banksianae, N. sertifer

G. frutetorum, N. lecontei, N. sertifer

swainei, $N$. virginianus complex

frutetorum, N. lecontei, N. n. nanulus,

frutetorum, $N$. n. nanulus, $N$. p. banksianae N. sertifer

G. hercyniae, N. abietis,
G. hercyniae, N. abietis 


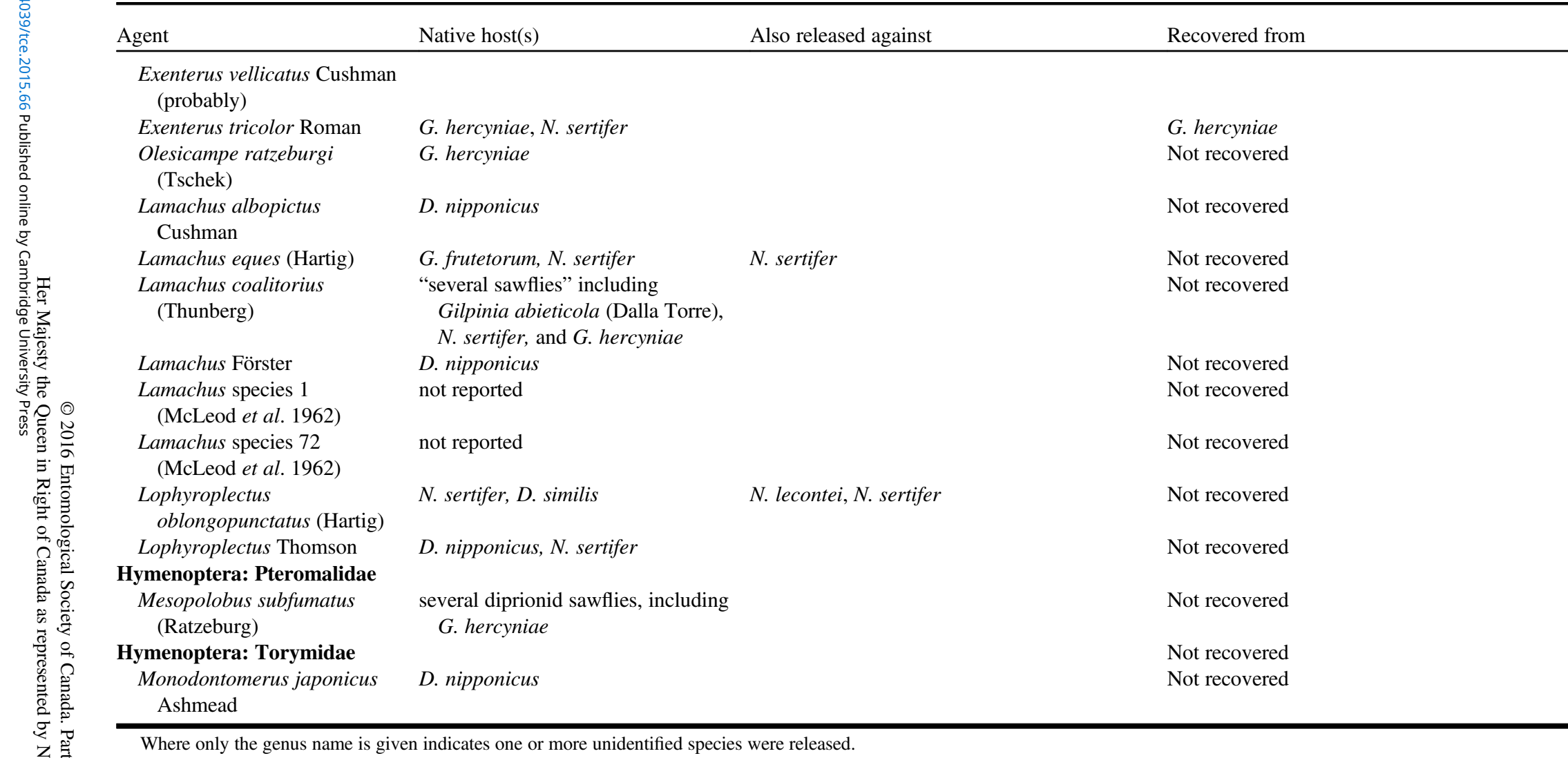

\footnotetext{
Where only the genus name is given indicates one or more unidentified species were released.
} 
targeted at the European pine sawfly had been first collected from this species in Europe as possible agents for the European spruce sawfly, and now were being redirected against their original host. Much like work targeting the balsam woolly adelgid, many agents were investigated and released against European pine sawfly for over 40 years with little or no significant impact. Control of the European pine sawfly was eventually achieved, but only through the development of a nucleopolyhedralvirus (Griffiths et al. 1984). This European pine sawfly programme is noteworthy in that it did see the first use of pre-release testing for biological control agents (Griffiths et al. 1971), and it was the subject of intensive population ecology studies (Holling 1959). Work on the dynamics of the European pine sawfly later influenced two successful projects that typified this post-war period: one against the non-native winter moth, Operophtera brumata (Linnaeus) (Lepidoptera: Geometridae), in Nova Scotia, and a renewed interest in the larch sawfly.

One of the major introduction programmes in Canada during this era was aimed at the winter moth, a defoliator of broadleaved, deciduous trees. This target was studied extensively in Europe before its discovery in North America during the early 1950s, and was known to be attacked by at least 63 parasitoids in its home range. The six most abundant species were selected for introduction into Canada (Embree 1971), two of which eventually established; Cyzenis albicans (Fallén) (Diptera: Tachinidae) and Agrypon flaveolatum (Gravenhorst) (Hymenoptera: Ichneumonidae). Releases of the other four agents were unsuccessful and discontinued to avoid competition with the first two agents that had established. Life table studies on winter moth populations in Nova Scotia were later used to quantify the impact of these released agents, along with other ecological factors (Embree 1966; Varley and Gradwell 1968). This work showed that the agents were able to keep moth populations low only if local weather conditions accelerated overwintering emergence before bud burst and led to larval starvation (Embree 1966). Roland (1988) and Roland and Embree (1995) later found that the released agents caused simple indirect mortality to the winter moth pupae by lengthening their time in the soil, thereby increasing their odds of predation by small mammals and ground-dwelling invertebrates.
The 1950s also saw a renewed effort against the larch sawfly, because $M$. tenthredinis, the most effective agent controlling it, had become ineffective by 1957 . This programme was actually the fifth effort targeting the sawfly, and the fourth since Hewitt's work in the 1910s. Throughout the 1920s, 1930s, and 1940s, parasitised sawfly larvae were collected near one of the first releases in Manitoba and redistributed to other parts of Canada (McGugan and Coppel 1962). Wong (1974) eventually showed that the sawfly's resistance to $M$. tenthredinis was because it could encapsulate the parasitoid's eggs and prevent them from hatching. The source of this resistance was thought to have come from the accidental introduction of a non-native sawfly strain from Europe during Hewitt's initial releases in the early 1900s (McGugan and Coppel 1962). Although yet to be confirmed, this suggests that the spectacular success of Hewitt's releases was in fact due to the target being the native strain of larch sawfly and therefore susceptible to $M$. tenthredinis, whereas after 1957, sawfly outbreaks were likely caused by the non-native sawfly strain that was resistant to the parasitoid.

A number of options were explored to suppress the renewed outbreaks of larch sawfly. For the first time, host testing was done to determine the best parasitoids to release and to estimate the potential for non-target effects (Ives and Muldrew 1984). However, some of these tests were done after the agents were released so there would have been little chance to prevent any unintended consequences. A rather unique programme was implemented against the sawfly in Newfoundland and Labrador when the masked shrew was released as an agent. Life table work in New Brunswick had shown that overwintering larch sawfly pupae suffered significant predation from small vertebrates, but Newfoundland lacked small predatory mammals. Unfortunately, once released, the masked shrew had no effect on larch sawfly populations, although it did contribute to European spruce sawfly control (Magasi and Syme 1984). Of greater concern was that the masked shrew populations expanded to become a nuisance over much of the island (Beirne and Kelleher 1973), illustrating the importance of non-target screening before release. In the rest of Canada, two new agents were released, M. tenthredinis from a European population 
that was not encapsulated by the sawfly, and Olesicampe benefactor (Thomson) (Hymenoptera: Ichneumonidae), another host-specific parasitoid showing promise (Turnock and Muldrew 1971). Based on initial success, $O$. benefactor was released across Canada up until 1981. It was later determined that a hyperparasitoid of $O$. benefactor, originally thought to be native only in Europe, also occurred in Canada and attacked $O$. benefactor, thereby limiting its effectiveness against the larch sawfly (Ives and Muldrew 1984).

As with winter moth, interactions between the larch sawfly, $O$. benefactor, and $M$. tenthredinis were examined in detail following their release, including studies on dispersal and life tables (Ives and Muldrew 1984). Unfortunately, larch sawfly populations collapsed during the late 1970s and this biological control programme ended without being fully assessed. No other larch sawfly outbreaks have been detected since, and the fate of $O$. benefactor and $M$. tenthredinis remains unknown. In a final wrinkle, Wong (1974) showed that the larch sawfly was a Holarctic species and likely had been present in North America since the Permian (250 mya). Early dendrochronological studies from across North America (reviewed by Ives and Muldrew 1984), and recent work from northern Canada by Nishimura and Laroque (2010), both suggest that the larch sawfly is native to North America, although its actual distribution remains uncertain. If Wong's hypothesis is correct, then the nonnative agents introduced by Hewitt during the early 1900s actually formed a "new association" that initially suppressed the native larch sawfly (Hewitt 1912; Glen 1956), but this was then disrupted by the inadvertent contamination and release of a resistant strain of European sawfly and its hyperparasitoids.

\section{The declining era: 1970-2000}

After 1970, biological control programmes in Canada became significantly smaller in both size and scope. The Belleville laboratory closed in 1972 as part of broader reductions across the federal government, and this severely constrained the resources available for forestry programmes. At the same time, aerial insecticide programmes expanded exponentially with focus on both chemical and biological applications (reviewed by Holmes and MacQuarrie 2016 and van Frankenhuyzen et al. 2015). Biological control projects that began after 1970 were of much smaller scope than earlier. However, this reduction also correlated with a higher degree of success than seen in the past.

Starting in 1970, the relocation of established non-native agents became a regular practice in Canada. Relocations had always been used as a technique to obtain parasitoids dating back to the first releases against the imported currantworm. However, because established agents were now readily available, this technique became popular, especially given limited resources. Numerous relocation examples could be cited here, including those for the spruce budworm and winter moth, but for brevity's sake, the following focusses on only a select few. Two egg parasitoids of European gypsy moth were released in Ontario from New Jersey during 1976 and 1980 (Griffiths and Quednau 1984). Successful introductions of Olesicampe geniculatae Quednau and Lim (Hymenoptera: Ichneumonidae) were made from Europe into Québec for control of the non-native mountain ash sawfly, Pristophora geniculata (Hartig) (Hymenoptera: Tenthredinidae) (Quednau 1990), and this agent was subsequently relocated to Newfoundland during the mid-1970s (West et al. 1994, 2002a). Four species of parasitoids from Europe and Japan were introduced into British Columbia between 1969 and 1980 against the non-native larch casebearer, Coleophora laricella (Hübner) (Lepidoptera: Coleophoridae), and two of these were later relocated from Montana to British Columbia (Otvos and Quednau 1984). There were also a number of relocations from Ontario to the island of Newfoundland of Lophyroplectus luteator Thunberg (Hymenoptera: Ichneumonidae) and $P$. basizonus, two agents originally released against the European spruce sawfly (Table 1), but now targeting the European pine sawfly. Finally, successful relocations of L. thomsoni from Alberta to the Northwest Territories, British Columbia, and Alaska against the non-native ambermarked birch leafminer were also made at the beginning of the 2000s (MacQuarrie et al. 2013a, 2013b; Soper et al. 2015).

There was very limited use of insect predators against forest pests in Canada post-1969. One bold biological control attempt was made against Swaine jack pine sawfly by introducing several 
predators into stands of jack pine, Pinus banksiana Lambert (Pinaceae), across Québec and Ontario (Finnegan and Smirnoff 1984). These predators included two species of red wood ant: (non-native Formica lugubris Zetterstedt (Hymenoptera: Formicidae) from Italy, and the native $F$. obscuripes Forel from Manitoba (Finnegan and Smirnoff 1984). The effectiveness of these ants on the target could not be assessed, but they were observed preying on other forest insect pests. Augmentative biological control with predators was also attempted against the holarctic balsam twig aphid, Mindarus abietinus Koch (Hemiptera: Mindaridae), using Chrysopa carnea Stephens (Neuroptera: Chrysopidae), Aphidoletes aphidimyaz (Rondani) (Diptera: Cecidomyidae), and Harmonia axyridis (Pallas) (Coleoptera: Coccinellidae). However, $H$. axyridis interfered with natural predation, and the establishment success of the other two species is unknown (Cloutier and Jean 2002). Finally, attempts were also made to augment the native predator, Lonchaea corticis Taylor (Diptera: Lonchaeidae), against the native white pine weevil, Pissodes strobi (Peck) (Coleoptera: Curculionidae), in order to increase its density above a critical threshold, but the agent could not be reared in the laboratory and the project was abandoned (Hulme and Kenis 2002). In the late 1990s, a similar effort was undertaken to assess the parasitoids associated with the terminal weevil, Pissodes nitidus Roelofs (Coleoptera: Curculionidae) in northeastern China with the intent of identifying agents that could be released against white pine weevil in Canada. Although the survey was completed (Hu et al. 2000) and two species were identified as possible agents (D. Langor, personal communication), the programme was cancelled in 1999 due to declining interest and funding in Canada.

A classic and often-cited example of conservation biological control involved the management of the non-native European pine shoot moth, Rhyacionia buoliana (Denis and Schiffermüller) (Lepidoptera: Tortricidae). Several agents were released between 1969 and 1973 in Ontario for this target (Reeks and Cameron 1971), but only one, Orgilus obscurator (Nees) (Hymenoptera: Braconidae), was found to be effective. Syme (1977) later showed that access to flowers, especially wild carrot, Daucus carota Linnaeus (Apiaceae), increased the parasitoid's effectiveness against the target by extending its lifespan and allowing for maximum fecundity.

One major augmentation biological control programme using a native egg parasitoid targeted against the native spruce budworm also occurred during this era, with successful strategies developed over a 15-year period to commercially rear and release the parasitoid (Smith et al. 1990, 2002). Efficacy studies and non-target risks showed this to be a promising option for protecting local, high value spruce forests. However, the programme was discontinued with the collapse of eastern spruce budworm across eastern North America in the mid-1990s.

Investigations continued into the biological control of European gypsy moth during the 1980 s and 1990s, leading to the development of two innovative tactics. The first was aimed at reducing the high rate of hyperparasitism seen on the European gypsy moth parasitoid, Cotesia melanoscela (Ratzeburg) (Hymenoptera: Braconidae) in North America. Nealis and Bourchier (1995) tested an Asian strain of C. melanoscela less vulnerable to hyperparasitism and recommended it for release (Nealis et al. 2002). However, these releases were never carried out. The second tactic attempted to find new natural enemies for European gypsy moth in Europe, this time focusing on those attacking low density host populations, with the rationale that these agents might be more effective at suppressing the target than those from high host densities. Previous agents released against the European gypsy moth had come from outbreak populations in Europe, but research was starting to show that natural enemy communities differed depending on European gypsy moth density (Nealis et al. 2002). In collaboration with CABI, a new agent, Aphantorhaphopsis samarensis (Villeneuve) (Diptera: Tachinidae), was discovered attacking low density populations in Europe, and interest shifted to introducing it against the European gypsy moth in Canada, as part of a new biological control strategy (Mills and Nealis 1992; Nealis and Quednau 1996). Beginning in 1990, A. samarensis was released into Ontario and New Brunswick (Nealis et al. 2002). However, few outbreaks of European gypsy moth have been seen in Canada since 1990, and the establishment of $A$. samarensis has not been evaluated. 
In the 1970s and 1980s, Canadian biological control practitioners clearly recognised the importance of testing parasitoids under field conditions before their release. In at least three cases these assessments were done for potential agents that were subsequently rejected. For instance, extensive pre-release testing was done above for A. samarensis against the European gypsy moth (Fuester et al. 2004), and field cage releases of Japanese and Austrian strains of Cephaloglypta murinanae (Bauer) (Hymenoptera: Ichneumonidae) and a species of Japanese Lissonota Gravenhorst (Hymenoptera: Ichneumonidae), were used to test potential agents against spruce budworm, in New Brunswick (Varty 1984). Two possible agents, Eubazus semirugosus (Ratzeburg) (Hymenoptera: Braconidae) and E. robustus (Nees), were tested against the white pine weevil but the latter was removed after laboratory and field cage studies found it was poorly synchronised with the target; the former was not pursued as funding stopped (Hulme and Kenis 2002). Although not strictly pre-release testing, Myxexoristops hertingi Mesnil (Diptera: Tachinidae) was released into cages on plantationgrown trees infested by non-native pine false webworm, Acantholyda erythrocephala (Linnaeus) (Hymenoptera: Pamphiliidae), to prevent dispersal of the low numbers of available parasitoids (Lyons 2013a). No parasitoids were subsequently recovered.

By the 1980s, creating "new associations" among non-native agents and native insects had fallen out of favour in biological control programmes. Projects during the early 1930s and 1940s had used this technique, but these tended not to be successful (e.g., Table 4), and subsequent work suggested that there was little evidence to support their implementation (Nealis and Wallace 1991; Wallace 1995). Only one attempt was made during this time to create a "new association" between a non-native agent and a native target with the introduction of Apanteles murinanae (Capek and Zwolfer) (Hymenoptera: Braconidae) against the spruce budworm (Mills 1983). This species was shown to have a slower developmental rate and a longer pre-oviposition period than its native congener, suggesting that it might be better synchronised with its host. A small release was made in Québec (Nealis and Wallace 1991), but it was not recovered and no further monitoring was done (Smith et al. 2002).
Spontaneous novel associations between native agents and non-native targets also started to be detected in the field during this era, and began to be exploited for introductions, most notably against the ambermarked birch leafminer (MacQuarrie et al. 2013a).

The century-old relationship between CABI in Europe and the Canadian Forest Service (CFS) was particularly important during the 1970s and 1980s. While the CFS had always funded CABI to collect and ship promising agents to Canada (Hulme 1982), during this era the relationship evolved into a stronger research collaboration, with CABI staff carrying out detailed biological studies on potential agents in Europe before shipping agents to Canada. Again, many projects could be cited here including most of the European gypsy moth work post-1980, but a few that have not been mentioned elsewhere include; the introduction of European parasitoids against the non-native birch casebearer, Coleophora serratella (Linnaeus) (Lepidoptera: Coleophoridae), into Newfoundland between 1968 and 1975 (Raske 1984), and the introduction of M. hertingi against the pine false webworm (Kenis and Kloosterman 2001). Work against the birch casebearer ended in the 1980s (Raske 1984) and the parasitoid of pine false webworm has not been recovered, although the sawfly population did collapse after the agent was released (Lyons 2013a). CABI's investigations on non-native agents for use against native seed cone maggots, Strobilomyia neanthracina Michelsen (Diptera: Anthomyiidae) and S. appalachenis Michelsen (Brockerhoff and Kenis 1997), suggested that introductions would not be warranted because the ecology of the parasitoids in Europe and North America were too similar (Sweeney et al. 2002). The same conclusions were reached for European agents targeted against the hemlock looper, spruce bud moth, and spruce seed moth, Cydia strobilella (Linnaeus) (Lepidoptera: Tortricidae). As a consequence, no biological control releases were attempted against these targets (West and Kenis 1997; Brockerhoff et al. 2002; West et al. 2002b).

One of the interesting aspects about biological control programmes during this era is the number of times decisions were made not to carry out releases, suggesting greater awareness of biological and ecological considerations, as well as potential 
risk to non-targets. While many of these projects were not successful at locating viable agents for control of native targets, the resources invested in these preliminary investigations likely resulted in significant savings compared to what would have been expended if full-scale, and likely unsuccessful, biological control programmes had been attempted. The lone successful project to occur during this period was the introduction of Lathrolestes nigricollis Thomson (Hymenoptera: Ichneumonidae) and Grypocentrus albipes Ruthe (Hymenoptera: Ichneumonidae) against the non-native birch leafminer, Fenusa pumila Leach (Hymenoptera: Tenthredinidae). These parasitoids were released during the 1970s in Québec and Newfoundland (Quednau 1984) and again into Alberta during the 1990s (Langor et al. 2002). One agent, L. nigricolls suppressed the leafminer in both eastern and western Canada, and the target is now much less dominant than it was before the release (MacQuarrie et al. 2013a).

\section{The current era: 2000 onwards}

The last 15 years have seen few biological control applications against forest insect pests in Canada. As evidence, only six of the 35 chapters in the review of Canadian biological control programmes between 2001 and 2012 were on insects attacking trees (Mason and Gillespie 2013). This period includes efforts against relatively minor pests, such as the pine false webworm (Lyons 2013a) and the ambermarked birch leafminer (MacQuarrie et al. 2013a, 2013b), but not against the most important pest species damaging Canadian forests, including the native mountain pine beetle, Dendroctonus ponderosae Hopkins (Coleoptera: Curculionidae). During this period five non-native wood-boring insects were discovered in eastern Canada: the Asian longhorned beetle, Anoplophora glabripennis (Motschulsky) (Coleoptera: Cerambycidae), the brown spruce longhorn beetle, Tetropium fuscum (Fabricius) (Coleoptera: Cerambycidae), the emerald ash borer, the European pine shoot beetle Tomicus piniperda (Linnaeus) (Coleoptera: Curculionidae), and Sirex noctilio Fabricius (Hymenoptera: Siricidae). Two of these species have arrived from Asia (Asian longhorned beetle and emerald ash borer) signalling a geographic shift in the origin of targets, from Europe to Asia.
Of these five species, only the emerald ash borer has been targeted for biological control (Table 1).

Exploration for potential biological control agents of emerald ash borer in China has resulted in the discovery, and eventual release into the United States of America of three species: Spathius agrili Yang (Hymenoptera: Braconidae), Tetrastichus planipennisi Yang (Hymenoptera: Eulophidae), and Oobius agrili Zhang and Huang (Hymenoptera: Encyrtidae) (Zhang et al. 2005; Yang et al. 2006; Ulyshen et al. 2010; Duan et al. 2011); T. planipennisi was obtained from the United States of America and released into Canada in 2013 and 2014 (D.B.L., personal observation). Spontaneous novel associations were also detected against the emerald ash borer and exploited for potential control (Lyons 2013b; Roscoe et al. 2015). The parasitoids of Asian longhorned beetle have been investigated in China and some augmentative releases have taken place there, but as yet no releases have been made in North America because the beetle continues to be eradicated (Turgeon and Smith 2013). No biological control agents have been released in Canada against the pine shoot beetle or S. noctilio. However, considerable information has been gained on their natural enemy assemblages, including "new associations" with native agents (Rudzik 2009; Ryan et al. 2013). A parasitic nematode, Deladenus siricidicola Bedding (Tylenchida: Neotylenchidae), that attacks the eggs and sterilises females of $S$. noctilio has been shown to be already present in Ontario, as have two parasitoids from the target's native range (Ryan et al. 2013). Moreover, native agents already appear to be regulating Canadian populations of both the pine shoot beetle (Rudzik 2009) and S. noctilio (Ryan et al. 2013). No biological control programmes have been attempted against the brown spruce longhorn beetle.

\section{Discussion}

Biological control in Canadian forests has been subjected to a number of reviews over the past century. Two key papers published in the early 1960s were critical of its potential, expressing concerns about the relative ad hoc nature of past introduction programmes (Turnbull and Chant 1961; McGugan and Coppel 1962). These authors were uneasy with both the lack of information on 
what was released and the limited number of follow-up studies carried out. They contended that early work had failed to properly screen material before release, and that this had led to contamination by other organisms, including resistant or virulent pest strains, multiple agents, and hyperparasitoids, and that this had compromised the releases (e.g., larch sawfly; Table 1). They also noted that past studies had surprisingly made little attempt to assess an agent's impact, in terms of its overall success. More importantly, these authors found there had been no real interest in examining the broader effects of the agents on possible non-targets. Their critiques also challenged the deliberate strategy of releasing multiple agents, as the potential for adverse competition among different agents was thought to be great. These two reviews appear to have been fairly influential, as later CABI reports attempted to address the issues raised by Turnbull and Chant (1961) and McGugan and Coppel (1962) (see Reeks and Cameron 1971).

In his review, Munroe (1971) agreed with many of the concerns expressed by the two early critiques, but he thought that they had somewhat overemphasised the importance of selectivity and need for caution, in part, based on a concern that criticism of biological control might lead to institutional paralysis and reduced capacity for future work. Beirne and Kelleher (1973) avoided this discussion, and instead turned to the issues of non-target effects and success. While they accepted that some undesirable consequences had occurred as a result of releases in the past, they did not consider them harmful enough to warrant real concern (Beirne and Kelleher 1973). On the other hand, they were very critical of the "apparent record of success" for biological control in Canada, arguing that $90 \%$ of all projects (they did not distinguish between forestry and agriculture programmes) were not really successful because $70 \%$ of the agents did not even establish. They were also disapproving of the mass-rearing approach to the production of agents (e.g., European spruce sawfly), contending that the release of large numbers of agents was not always the best way to guarantee establishment, in particular when the agent had had no previous relationship with the target (e.g., Table 4).

It is difficult to evaluate the effect of these early assessments on biological control programmes in
Canadian forests. Coincidently perhaps, around the same time as Turnbull and Chant's (1961) review, biological control began to decline as an overall tactic in forestry (Figs. 1-2), and it is unclear whether these two events can be related. Recommendations made by Munroe (1971) to improve biological control practice do not appear to have been adopted, and it is apparent that even though biological control studies continued, they were significantly smaller and releases much less frequent. During the 1970s, debate seemed to center around the relative merits of single versus multiple agent releases (Beirne and Kelleher 1973), but again, the discussion appears to have died out by the early 1980s without resolving this question. Unfortunately, disregarding these key biological control issues seems to have had little impact on the strategies used by subsequent programmes, as a decline in resources available to find, rear, and release large numbers of agents has only allowed a few agents to be considered at any one time since.

After the debates of the 1960s and 1970s, the reviews of biological control published during the 1980s and 1990s were more positive. Drawing from leading-edge ecological research, Hulme and Green (1984) emphasised the role of selecting the proper agents for release and taking into account the population dynamics of the target; they also supported a role for novel associations. In their later review, Nealis and Wallace (1991) described biological control against forest insects in Canada as "very successful", arguing that agents tended to establish at higher rates in stable forest systems than in others, and that biological control was more likely to work in harmony with such natural systems, and be more accepted by the public. These authors also agreed that novel associations and inundative releases had a place in forest biological control. Wallace (1995) later reiterated these views, and gave a generally positive assessment of biological control in Canadian forests, the last broad overview of its kind.

Our assessment of biological control in Canadian forests is cautiously optimistic. Clearly, a number of targets have been brought under control by these programmes, but many share undesirable characteristics when measured by today's standards (Myers 1989). The goal of the earliest programmes was to establish, or re-establish, a natural balance between targets and their multiple 
agents, and as a result, projects during the 1930s and 1940s introduced as many species as possible in the hope that one would establish, and little attempt was made to find a strong ecological match; e.g., numerous agents were released against the European spruce sawfly with no known history of attack (Table 4). Oddly, the first successful biological control project against the larch sawfly was an exception to this multiple agent strategy in that studies from the target's native range provided the rationale to introduce only one effective agent (Hewitt 1912). The release of polyphagous agents with broad host ranges was another strategy used in these early programmes, notably against the European gypsy moth and browntail moth, based on the belief that this was a desirable trait and would facilitate survival when the target was not present (or had been driven to extinction). Perhaps one lesson learned during this period was that non-target effects were important, and that generalist predators, even when successful against their target (e.g., C. concinnata), were unlikely to be good agents for release because of this potential for broader, unanticipated impact (Buckner 1959; Schooley et al. 1984; Hulme and Kenis 2002).

The motivation to suppress target populations, at least in the early days of biological control, was rooted in the desire to prevent damage to trees, rather than for economic or ecological reasons. This motivation is evident in the selection of targets from the 1930s through to the 1970s (Tables 1, 4; Fig. 1). Many targets did not kill trees or even cause economic damage, and certainly their ecological or social effects were rarely considered. Some programmes were only viable because "surplus" agents were available (e.g., those agents produced by the Belleville laboratory for the suppression of European spruce sawfly). What is most troubling at this time is that many of these "targets of opportunity" were native insects (Table 4), and while occasionally injurious to trees, were probably well adapted and co-evolved with many natural enemies. Over the years, economic considerations were often cited as the reason to start biological control programmes, but in the end, economic loss or benefit was never really evaluated. This apparent lack of desire (or need) to assess programmes strictly in terms of costs and benefits is surprising, although one might say not unique to biological control. In fact, the entire last century of forest pest management in Canada seems to have curiously missed requiring any real economic or environmental analysis to justify its use.

Classical biological control has been the dominant tactic used in Canadian forests over the past century, appropriately reflecting the emphasis on non-native targets introduced without their suite of natural enemies. This trend persists to the present day, even though work during the 1970s and 1980s attempted to include other strategies such as conservation and augmentation. Syme's (1977) research on European pine shoot moth showed the value of working with vegetation and landscapes to conserve natural enemies, as did more recent studies of hemlock looper (Hebert and Brodeur 2002). Such examples of conservation biological control are the exceptions though, as no other efforts have been undertaken in Canadian forests. Augmentation strategies using inundative releases or the development of "new associations" in introduction biological control, have similarly been absent from biological control programmes since the 1980s. Inundative releases of a native egg parasitoid against the spruce budworm during the 1980s and 1990s showed that it could reduce populations and prevent defoliation (Smith et al. 1990); however, the project was discontinued when spruce budworm populations collapsed and before commercial production and application could be made viable. One new development in biological control for Canada has been the use of insect agents to suppress non-native vegetation in southern Ontario forests; i.e., dog-strangling vine, Cynanchum rossicum (Linneaus) (Apocynaceae) (S.M.S., personal observation). This project represents the first attempt at weed biological control in Canadian forestry, and if successful, could be significant for future restoration projects in disturbed natural habitats.

Success in classical biological control programmes is often measured by whether the agent becomes established and provides long-term, significant control of its target in the new range. Such a simple definition must be extended to include alternative strategies, such as conservation and augmentation biological control. In this review, we have defined success in two ways, one using the classic definition of established, long-term control, and a second that relaxes the standard for long-term suppression slightly to allow for better 
evaluation of augmentation strategies (Table 3). In the latter case, the agent may make a contribution to the control of the target, but other mortality factors may also be required in order to achieve complete suppression. Using these definitions provides for a more nuanced view of success in biological control programmes and a more comprehensive measure of effectiveness of agents. By refining the meaning of success, the significant historical role biological control has played in the management of Canadian forests becomes clearer.

Historically, Canada has been a world leader in the field of biological control for forest insects (Pschorn-Walcher 1977; Kelleher and Hulme 1984; Smith 1993), and many of its biological control programmes have been considered successful (e.g., Munroe 1971; Hulme 1988; Wallace 1995). Much of this success is rooted in the extensive population studies and basic research typical of Canadian forest entomology (Nealis and Wallace 1991; Quiring et al. 2015). Yet despite this impressive track record, biological control programmes have been on the decline in Canada since the 1960s (Fig. 1). As of 2014, only a handful of active projects remain, all targeting the emerald ash borer in Ontario (Lyons 2013b). The last active programme was completed during the mid-2000s against ambermarked birch leafminer, and even this involved only the relocation of agents within Canada (MacQuarrie et al. 2013b). All of this raises concern about Canada's capacity to accomplish large-scale or concurrent biological control programmes into the future. Although critical infrastructure has been retained, along with new facilities capable of producing large numbers of biological agents (e.g., Natural Resources Canada's CFS Insect Production Services Unit in Sault Ste. Marie, Ontario; Government of Canada 2013), few biological control practitioners remain in any research capacity, and there are no longer any formal university programs for training. Nealis and Wallace (1991) stated that the future of biological control introductions in forestry would depend on continuing strong, historic ties with CABI. While agriculture has retained these, the last major forestry project with CABI was in the early 2000s against the pine false webworm (Lyons 2013a).

All evidence suggests that when the right conditions are met, biological control is a viable option for managing Canada's forest pests. Canadian practitioners also appear capable of significant innovation in the application of biological control methods. Despite this, biological control in Canadian forestry is at a present-day low, one not seen since the early 1900 s when the first programmes began. Whether this is a permanent or temporary position is unknown. In either case, biological control seems unlikely to play a significant role in managing Canada's non-native forest pests over the immediate future, with possibly the notable exception of the emerald ash borer. Many unanswered questions remain from the projects described here, and there is ample room for the research and development of novel methods and techniques against native and non-native pests alike (e.g., Smith et al. 1990; Mills and Nealis 1992; Hebert and Brodeur 2002). These are all potentially profitable areas for research and development that, if addressed, would help make better pest management decisions for our forests in the face of coming invasions.

\section{Acknowledgements}

The authors thank the volume editors for their invitation to take on this daunting task of reviewing the vast literature on biological control in Canadian forests, and two anonymous reviewers for their insightful comments. Most importantly, they extend a deep thanks to the hundreds of biological control researchers who have contributed to this important research over the past 130 years, and hope that this review, in some way, accurately represents their work.

\section{References}

Armstrong, J.A. and Ives, W.G.H. 1995. Forest insect pests in Canada. Natural Resources Canada, Canadian Forest Service, Ottawa, Ontario, Canada.

Balch, R.E. 1960. The approach to biological control in forest entomology. The Canadian Entomologist, 92: 297-310. doi:10.4039/Ent92297-4.

Beirne, B.P. 1973. Influences on the development and evolution of biological control in Canada. Bulletin of the Entomological Society of Canada, 5: 85-89.

Beirne, B.P. 1975. Biological control attempts by introductions against pest insects in the field in Canada. The Canadian Entomologist, 107: 225-236. doi:10.4039/Ent107225-3.

Beirne, B.P. and Kelleher, J.S. 1973. Early biological control attempts in Canada. Journal of the Entomological Society of British Columbia, 70: 39-40. 
Bird, F.T. and Elgee, D.E. 1957. A virus disease and introduced parasites as factors controlling the European spruce sawfly, Diprion hercyniae (Htg.), in central New Brunswick. The Canadian Entomologist, 89: 371-378. doi:10.4039/Ent89371-8.

Brockerhoff, E.G. and Kenis, M. 1997. Oviposition, life cycle and parasitoids of the spruce cone maggot, Strobilomyia anthracina (Diptera: Anthomyiidae), in the Alps. Bulletin of Entomological Research, 87: 555-562. doi:10.1017/S0007485300038645.

Brockerhoff, E.G., Kenis, M., and Turgeon, J.J. 2002. Cydia strobilella (L.), spruce seed moth (Lepidoptera: Tortricidae). In Biological control programmes in Canada, 1981-2000. Edited by P.G. Mason and J.T. Huber. CABI Publishing, Oxford, United Kingdom. Pp. 94-99.

Buckner, C.H. 1959. The assessment of larch sawfly coccoon predation by small mammals. The Canadian Entomologist, 91: 275-292. doi:10.4039/Ent91275-5.

Clark, R.C., Greenbank, D.O., Bryant, D.G., and Harris, J.W.E. 1971. Adelges piceae (Ratz.), balsam woolly aphid (Homoptera: Adelgidae). In Biological control programmes against insects and weeds in Canada 1959-1968. Commonwealth Agricultural Bureaux, Farnham Royal, Slough, United Kingdom. Pp. 113-127.

Cloutier, C. and Jean, C. 2002. Mindarus abietinus Koch, balsam twig aphid (Hemiptera: Mindaridae). In Biological control programmes in Canada, 1981-2000. Edited by P.G. Mason and J.T. Huber. CABI Publishing, Wallingford, United Kingdom. Pp. 185-190.

Dowden, P.B. 1962. Parasites and predators of forest insects liberated in the United States through 1960. Agriculture Handbook 226. United States Department of Agriculture, Forest Service, Washington, District of Columbia, United States of America.

Duan, J.J., Bauer, L.S., Ulyshen, M.D., Gould, J.R., and Van Driesche, R. 2011. Development of methods for the field evaluation of Oobius agrili (Hymenoptera: Encyrtidae) in North America, a newly introduced egg parasitoid of the emerald ash borer (Coleoptera: Buprestidae). Biological Control, 56: 170-174. doi:10.1016/j.biocontrol.2010.11.009.

Eilenberg, J., Hajek, A., and Lomer, C. 2001. Suggestions for unifying the terminology of biological control. BioControl, 46: 387-400. doi:10.1023/ A:1014193329979.

Elkinton, J.S. and Boettner, G. 2012. Benefits and harm caused by the introduced generalist tachinid, Compsilura concinnata, in North America. BioControl, 57: 277-288. doi:10.1007/s10526-011-9437-8.

Embree, D.G. 1966. The role of introduced parasites in the control of the winter moth in Nova Scotia. The Canadian Entomologist, 98: 1159-1168. doi:10.4039/ Ent981159-11.

Embree, D.G. 1971. Operophtera brumata (L.), winter moth (Lepidoptera: Geometridae). In Biological control programmes against insects and weeds in Canada 1959-1968. Commonwealth Agricultural Bureaux, Farnham Royal, Slough, United Kingdom. Pp. 167-175.
Finnegan, R.J. and Smirnoff, W.A. 1984. Neodiprion swainei (Middleton), Swaine jack pine sawfly (Hymenoptera: Diprionidae). In Biological control programmes against insects and weeds in Canada 1969-1980. Edited by J.S. Kelleher and M.A. Hulme. Commonwealth Agricultural Bureaux, Farnham Royal, Slough, United Kingdom. Pp. 341-348.

Fuester, R.W., Swan, K.S., Kenis, M., and Hérard, F. 2004. Determining the host range of Aphantorhaphopsis (= Ceranthia) samarensis, a relatively specialized tachinid introduced against the gypsy moth. In Assessing host range for parasitoids and predators used for classical biological control: a guide to best practice. Edited by R. Van Driesche and R. Reardon. FHTET-2004-03. United States Department of Agriculture Forest Service-Forest Health Technology Enterprise Team, Morgantown, West Virginia, United States of America. Pp. 177-194.

Furniss, M.M. 2010. Beginnings of American forest entomology: the role of Andrew Delmar Hopkins. American Entomologist, 56: 78-87.

Glen, R. 1956. Entomology in Canada up to 1956: a review of developments and accomplishments. The Canadian Entomologist, 88: 290-371. doi:10.4039/ Ent88290-7.

Godfray, H.C.J. 1994. Parasitoids: behavioral and evolutionary ecology. Princeton University Press, Princeton, New Jersey, United States of America.

Government of Canada. 2013. The insect production and quarantine laboratories. Frontline Express Bulletin 69. Natural Resources Canada, Canadian Forest Service, Great Lakes Forestry Centre, Sault Ste. Marie, Ontario, Canada.

Greathead, D.J. 1994. History of biological control. Antenna, 18: 187-199.

Griffiths, K.J., Cunningham, J.C., and Otvos, I.S. 1984. Neodiprion sertifer (Geoffroy), European pine sawfly (Hymenoptera: Diprionidae). In Biological control programmes against insects and weeds in Canada 1969-1980. Edited by J.S. Kelleher and M.A. Hulme. Commonwealth Agricultural Bureaux, Farnham Royal, Slough, United Kingdom. Pp. 331-340.

Griffiths, K.J. and Quednau, F.W. 1984. Lymantria dispar (L.), gypsy moth (Lepidoptera: Lymantriidae). In Biological control programmes against insects and weeds in Canada 1969-1980. Edited by J.S. Kelleher and M.A. Hulme. Commonwealth Agricultural Bureaux, Farnham Royal, Slough, United Kingdom. Pp. 303-310.

Griffiths, K.J., Rose, A.H., and Bird, F.T. 1971. Neodiprion sertifer (Geoff.), European pine sawfly (Hymenoptera: Diprionidae). In Biological control programmes against insects and weeds in Canada 1959-1968. Commonwealth Agricultural Bureaux, Farnham Royal, Slough, United Kingdom. Pp. 150-162.

Gurr, G. and Wratten, S. 2000. Biological control: measures of success. Kluwer Academic Publishers, Dordrecht, The Netherlands. 
Hall, R.W., Ehler, L.E., and Bisabri-Eshadi, B. 1980. Rate of success in classical biological control of arthropods. Bulletin of the Entomological Society of America, 26: 111-114. doi:10.1093/besa/26.2.111.

Hebert, C. and Brodeur, J. 2002. Lambdina fiscellaria (Guenee), hemlock looper (Lepidoptera: Geometridae). In Biological control programmes in Canada 2001-2012. Edited by P.G. Mason and D. Gillespie. CABI Publishing, Wallingford, United Kingdom. Pp. 203-207.

Hewitt, C.G. 1912. The large larch sawfly (Nematus erichsonii) with an account of its parasites, other natural enemies and means of control. Bulletin $10-$ second series. Dominion of Canada Department of Agriculture, Ottawa, Ontario, Canada.

Holling, C. 1959. The components of predation as revealed by a study of small-mammal predation of the European pine sawfly. The Canadian Entomologist, 91: 293-320. doi:10.4039/Ent91293-5.

Holmes, S.B. and MacQuarrie, C.J.K. 2016. Chemical control in forest pest management. The Canadian Entomologist, doi:10.4039/tce.2015.71.

Hopper, K.R. and Roush, R.T. 1993. Mate finding, dispersal, number released and the success of biological control introductions. Ecological Entomology, 18: 321-331. doi:10.1111/j.1365-2311. 1993.tb01108.x.

Hu, C.-X., Li, C.-D., Wang, Z.-Y., Langor, D., Yue, S.-K., Liu, K.-Y., and Han, S.-I. 2000. Study on the parasitoids of Pissodes nitidus Roel. Journal of Forestry Research, 11: 213-214. doi:10.1007/ BF02855528.

Hulme, M.A. 1982. Biological control in the Canadian Forestry Service. Report DPC-X-11. Environment Canada, Canadian Forestry Service, Ottawa, Ontario, Canada.

Hulme, M.A. 1988. The recent Canadian record in applied biological control of forest insect pests. The Forestry Chronicle, 64: 27-31. doi:10.5558/ tfc64027-1.

Hulme, M.A. and Green, G.W. 1984. Biological control of forest insect pests in Canada 1969-1980: retrospect and prospect. In Biological control programmes against insects and weeds in Canada 1969-1980. Edited by J.S. Kelleher and M.A. Hulme. Commonwealth Agricultural Bureaux, Farnham Royal, Slough, United Kingdom. Pp. 215-227.

Hulme, M.A. and Kenis, M. 2002. Pissodes strobi (Peck), white pine weevil (Coleoptera: Curculionidae). In Biological control programmes in Canada, 1981-2000. Edited by P.G. Mason and J.T. Huber. CABI Publishing, Wallingford, United Kingdom. Pp. 221-228.

Ives, W.G.H. and Muldrew, J.A. 1984. Pristophora erichsonii (Hartig), larch sawfly (Hymenoptera: Tenthredinidae). In Biological control programmes against insects and weeds in Canada 1969-1980. Edited by J.S. Kelleher and M.A. Hulme. Commonwealth Agricultural Bureaux, Farnham Royal, Slough, United Kingdom. Pp. 369-380.
Keever, C.C., Nieman, C., Ramsay, L., Ritland, C.E., Bauer, L.S., Lyons, D.B., and Cory, J.S. 2012. Microsatellite population genetics of the emerald ash borer (Agrilus planipennis Fairmaire): comparisons between Asian and North American populations. Biological Invasions, 15: 1537-1559. doi:10.1007/ s10530-012-0389-4.

Kelleher, J.S. and Hulme, M.A. 1984. Biological control programmes against insects and weeds in Canada 1969-1980. Commonwealth Agricultural Bureaux, Farnham Royal, Slough, United Kingdom. Kenis, M. and Kloosterman, K. 2001. European parasitoids of the pine false webworm (Acantholyda erythocephala (L.)) and their potential for biological control in North America. In Proceedings: integrated management and dynamics of forest defoliating insects: Victoria, British Columbia, August 15-19 1999. Edited by A.M. Liebhold, M.L. McManus, I.S. Otvos, and S.L.C. Fosbroke. General Technical Report NE-277. United States Department of Agriculture, Forest Service, Newtown Square, Pennsylvania, United States of America. Pp. 65-73.

Langor, D.W., Cameron, E.K., MacQuarrie, C.J.K., McBeath, A., McClay, A., Peter, B., et al. 2014. Non-native species in Canada's boreal zone: diversity, impacts, and risk. Environmental Reviews, 22: 372-420. doi:10.1139/er-2013-0083.

Langor, D.W., Digweed, S.C., and Spence, J.R. 2002. Fenusa pusilla (LePeletier), birch leafminer, and Profenusa thomsoni (Konow), ambermarked birch leafminer (Hymenoptera: Tenthredinidae). In Biological control programmes in Canada, 1981-2000. Edited by P.G. Mason and J.T. Huber. CABI Publishing, Wallingford, United Kingdom. Pp. 123-127.

Lyons, D.B. 2013a. Acantholyda erythrocephala L., pine false webworm (Hymenoptera: Pamphiliidae). In Biological control programmes in Canada 2001-2012. Edited by P.G. Mason and D. Gillespie. CABI Publishing, Wallingford, United Kingdom. Pp. 54-56.

Lyons, D.B. 2013b. Agrilus planipennis Fairmaire, emerald ash borer (Coleoptera: Buprestidae). In Biological control programmes in Canada 2001-2012. Edited by P.G. Mason and D. Gillespie. CABI Publishing, Wallingford, United Kingdom. Pp. 62-72.

MacQuarrie, C.J.K., Langor, D.W., Digweed, S.C., and Spence, J.R. 2013a. Fenusa pumila Leach, birch leaf miner, Profenusa thomsoni (Konow), ambermarked birch leaf miner (Hymenoptera: Tenthredinidae). In Biological Control Programmes in Canada 2001-2012. Edited by P.G. Mason and D. Gillespie. CABI Publishing, Wallingford, United Kingdom. Pp. 175-181.

MacQuarrie, C.J.K., Williams, D.J., and Langor, D.W. 2013b. Update on the establishment of birch leafminer parasitoids in western Canada. Journal of the Entomological Society of British Columbia, 110: 35-37. 
Magasi, L.P. and Syme, P.D. 1984. Gilpinia hercyniae (Hartig), European spruce sawfly (Hymenoptera: Diprionidae). In Biological control programmes against insects and weeds in Canada 1969-1980. Edited by J.S. Kelleher and M.A. Hulme. Commonwealth Agricultural Bureaux, Farnham Royal, Slough, United Kingdom. Pp. 295-298.

Mason, P.G. and Gillespie, D.R. 2013. Biological control programmes in Canada 2001-2012. CABI Publishing, Wallingford, United Kingdom.

Mason, P.G. and Huber, J.T. 2002. Biological control programmes in Canada, 1981-2000. CABI Publishing, Wallingford, United Kingdom.

McGugan, B.M. and Coppel, H.C. 1962. Part II Biological control of forest insects, 1910-1958. In A review of the biological control attempts against insects and weeds in Canada. Commonwealth Agricultural Bureaux, Farnham Royal, Bucks, United Kingdom. Pp. 35-115.

McLeod, J.H., McGugan, B.M., and Coppel, H.C. 1962. Part I - Biological control of pests of crops, fruit trees, ornamentals and weeds in Canada up to 1959. In A review of the biological control attempts against insects and weeds in Canada. Commonwealth Agricultural Bureaux, Farnham Royal, Bucks, United Kingdom. Pp. 1-34.

Mills, N.J. 1983. Possibilities for the biological control of Choristoneura fumiferana (Clemens) using natural enemies from Europe. Biological News and Information, 4: 103-125.

Mills, N.J. and Nealis, V.G. 1992. European field collections and Canadian releases of Ceranthia samarensis (Dipt.: Tachinidae), a parasitoid of the gypsy moth. Entomophaga, 37: 181-191. doi: 10.1007/BF02372416.

Munroe, E.G. 1971. Status and potential of biological control in Canada. In Biological control programmes against insects and weeds in Canada 1959-1968. Commonwealth Agricultural Bureaux, Farnham Royal, Slough, United Kingdom. Pp. 213-255.

Myers, J.H., Higgins, C., and Kovacs, E. 1989. How many insect species are necessary for the biological control of insects? Environmental Entomology, 18: 541-547. doi:10.1093/ee/18.4.541.

Nealis, V.G. and Bourchier, R.S. 1995. Reduced vulnerability to hyperparasitism in nondiapause strains of of Cotesia melanoscela (Ratzeburg) (Hymenoptera: Braconidae). Proceedings of the Entomological Society of Ontario, 126: 29-35.

Nealis, V.G., Carter, N., Kenis, M., Quednau, F.W., and van Frankenhuyzen, K. 2002. Lymantria dispar (L.), gypsy moth (Lepidoptera: Lymantriidae). In Biological control programmes in Canada, 1981-2000. Edited by P.G. Mason and J.T. Huber. CABI Publishing, Wallingford, United Kingdom. Pp. 159-168.

Nealis, V.G. and Quednau, F.W. 1996. Canadian field releases and overwintering survival of Ceranthia samarensis (Villeneuve) (Diptera: Tachinidae) for biological control of the gypsy moth, Lymantria dispar (L.) (Lepidoptera: Lymantriidae). Proceedings of the Entomological Society of Ontario, 127: 11-20.
Nealis, V.G. and Wallace, D.R. 1991. Biological control of forest pests by insect parasitoids. In Biological control of pests in Canada. Edited by A.S. McClay. Alberta Environmental Centre, Vegreville, Alberta, Canada. Pp. 15-22.

Neilson, M.M., Martineau, R., and Rose, A.H. 1971. Diprion hercyniae (Hartig), European spruce sawfly. In Biological control programmes against insects and weeds in Canada 1959-1968. Commonwealth Agricultural Bureaux, Farnham Royal, Slough, United Kingdom. Pp. 136-143.

Neilson, M.M. and Morris, R.F. 1964. The regulation of European spruce sawfly numbers in the Maritime provinces of Canada from 1937 to 1963. The Canadian Entomologist, 96: 773-784. doi:10.4039/ Ent96773-5.

Nishimura, P.H. and Laroque, C.P. 2010. Tree-ring evidence of larch sawfly outbreaks in western Labrador, Canada. Canadian Journal of Forest Research, 40: 1542-1549. doi:10.1139/X10-091.

Otvos, I.S. and Quednau, F.W. 1984. Coleophora laricella (Hübner), larch casebearer (Lepidoptera: Coleophoridae). In Biological control programmes against insects and weeds in Canada 1969-1980. Edited by J.S. Kelleher and M.A. Hulme. Commonwealth Agricultural Bureaux, Farnham Royal, Slough, United Kingdom. Pp. 285-289.

Price, P.W. and Tripp, H.A. 1972. Activity patterns of parasitoids on the Swaine jack pine sawfly, Neodiprion swainei (Hymenoptera: Diprionidae), and parasitoid impact on the host. The Canadian Entomologist, 104: 1003-1016. doi:10.4039/Ent1041003-7.

Pschorn-Walcher, H. 1977. Biological control of forest insects. Annual Review of Entomology, 22: 1-22. doi:10.1146/annurev.en.22.010177.000245.

Quednau, F.W. 1984. Fenusa pusilla (LePeletier), birch leaf-miner (Hymenoptera: Tenthredinidae). In Biological control programmes against insects and weeds in Canada 1969-1980. Edited by J.S. Kelleher and M.A. Hulme. Commonwealth Agricultural Bureaux, Farnham Royal, Slough, United Kingdom. Pp. 291-294.

Quednau, F.W. 1990. Introduction, permanent establishment, and dispersal in eastern Canada of Olesicampe geniculatae Quednau and Lim (Hyemenoptera: Ichneumonidae), an important biological control agent of the mountain ash sawfly, Pristophora geniculata (Hartig) (Hymenoptera: Tenthredinidae). The Canadian Entomologist, 122: 921-934.

Quiring, D., Quiring, V., Quiring, A-M., and Edwards, S. 2015. Historical trends in Canadian forest entomology. The Canadian Entomologist, doi:10.4039/ tce.2015.21.

Raske, A.G. 1984. Coleophora serratella (L.), birch casebearer (Lepidoptera: Coleophoridae). In Biological control programmes against insects and weeds in Canada 1969-1980. Edited by J.S. Kelleher and M.A. Hulme. Commonwealth Agricultural Bureaux, Farnham Royal, Slough, United Kingdom. Pp. 285-289. 
Reeks, W.A. and Cameron, J.M. 1971. Part III current approach to biological control of forest insects. In Biological control programmes against insects and weeds in Canada 1959-1968. Commonwealth Agricultural Bureaux, Farnham Royal, Slough, United Kingdom. Pp. 105-212.

Richmond, H.A. 1983. Forever green. Olichan Books, Fernie, British Columbia, Canada.

Riegert, P.W. 1980. From arsenic to DDT: a history of entomology in western Canada. University of Toronto Press, Toronto, Ontario, Canada.

Roland, J. 1988. Decline in winter moth populations in North America: direct versus indirect effect of introduced parasites. Journal of Animal Ecology, 57: 523-531. doi:10.2307/4922.

Roland, J. and Embree, D.G. 1995. Biological control of the winter moth. Annual Review of Entomology, 40: 475-492. doi:10.1146/annurev.en.40.010195.002355.

Roscoe, L.E., Lyons, D.B., Ryall, K.L., and Smith, S.M. 2015. Courtship sequence and evidence of volatile pheromones in Phasgonophora sulcata (Hymenoptera: Chalcididae), a North American parasitoid of the invasive Agrilus planipennis (Coleoptera: Buprestidae). The Canadian Entomologist. doi:10.4039/tce.2015.52.

Rudzik, N. 2009. Reproduction, competition, and predation after establishment of introduced populations of the greater European pine shoot beetle, Tomicus piniperda (L.) (Coleoptera: Curculionidae, Scolytinae). PhD Dissertation. University of Toronto, Toronto, Ontario, Canada.

Ryan, K., Smith, S.M., and Turgeon, J.J. 2013. Sirex noctilio Fabricius, (Hymenoptera: Siricidae). In Biological control programmes in Canada 2001-2012. Edited by P.G. Mason and D. Gillespie. CABI Publishing, Wallingford, United Kingdom. Pp. 263-268.

Schooley, H.O., Harris, J.W.E., and Pendrel, B. 1984. Adelges piceae (Ratz.), balsam woolly adelgid (Homoptera: Adelgidae). In Biological control programmes against insects and weeds in Canada 1969-1980. Edited by J.S. Kelleher and M.A. Hulme. Commonwealth Agricultural Bureaux, Farnham Royal, Slough, United Kingdom. Pp. 229-234.

Simmonds, F.J., Franz, J.M., and Sailer, R.I 1976. History of biological control. In Theory and practice of biological control. Edited by C.B. Huffaker and P.S. Messenger. Academic Press, New York, New York, United States of America. Pp. 17-39.

Smith, S.M. 1993. Insect parasitoids: a Canadian perspective on their use for biological control of forest insect pests. Phytoprotection, 74: 51-67. doi:10.7202/706036ar.

Smith, S.M., van Frankenhuyzen, K., Nealis, V.G., and Bourchier, R.S. 2002. Choristoneura fumiferana (Clemens), eastern spruce budworm (Tortricidae). In Biological control programmes in Canada, 1981-2000. Edited by P.G. Mason and J.T. Huber. CABI Publishing, Wallingford, United Kingdom. Pp. 58-68.
Smith, S.M., Wallace, D.R., Howse, G., and Meating, J. 1990. Suppression of spruce budworm populations by Trichogramma minutum Riley 1982-1986. Memoirs of the Entomological Society of Canada, 122: 56-81. doi:10.4039/entm122153056-1.

Soper, A.L., MacQuarrie, C.J.K., and van Driesche, R. 2015. Introduction, establishment, and impact of Lathrolestes thomsoni (Hymenoptera: Ichneumonidae) for biological control of the ambermarked birch leafminer, Profenusa thomsoni (Hymenoptera: Tenthredinidae), in Alaska. Biological Control, 83: 13-19. doi:10.1016/j.biocontrol.2014. 12.018.

Sperling, F.A.H., Raske, A.G., and Otvos, I.S. 1999. Mitochondrial DNA sequence variation among populations and host races of Lambdina fiscellaria (Gn.) (Lepidoptera: Geometridae). Insect Molecular Biology, 8: 97-106. doi:10.1046/j.1365-2583.1999. 810097.x.

Sweeney, J.D., Brockerhoff, E.G., Kenis, M., and Turgeon, J.J. 2002. Strobilomyia neanthracina Michelsen and $S$. appalachensis, spruce cone maggots (Diptera: Anthomyiidae). In Biological control programmes in Canada, 1981-2000. Edited by P.G. Mason and J.T. Huber. CABI Publishing, Wallingford, United Kingdom. Pp. 253-258.

Syme, P.D. 1977. Observations on the longevity and fecundity of Orgilus obscurator (Hymenoptera: Braconidae) and the effects of certain foods on longevity. The Canadian Entomologist, 109: 995-1000. doi:10.4039/Ent109995-7.

Thompson, W.R. 1939. Biological control and the theories of the interactions of populations. Parasitology, 31: 299-388. doi:10.1017/S0031182 000012865.

Timms, L.L., Walker, S.C., and Smith, S.M. 2011. Establishment and dominance of an introduced herbivore has limited impact on native hostparasitoid food webs. Biological Invasions, 14: 229-244. doi:10.1007/s10530-011-9999-5.

Turgeon, J.J. and Smith, M.T. 2013. Anoplophora glabripennis (Molschulsky), Asian longhorned beetle (Coleoptera: Cerambycidae). In Biological control programmes in Canada 2001-2012. Edited by P.G. Mason and D. Gillespie. CABI Publishing, Wallingford, United Kingdom. Pp. 82-92.

Turnbull, A.C. and Chant, D.A. 1961. The practice and theory of biological control in Canada. Canadian Journal of Zoology, 39: 697-753. doi:10.1139/ z61-071.

Turnock, W.J. and Muldrew, J.A. 1971. Pristiphora erichsonii (Hartig), larch sawfly (Hymenoptera: Tenthredinidae). In Biological control programmes against insects and weeds in Canada 1959-1968. Commonwealth Agricultural Bureaux, Farnham Royal, Slough, United Kingdom. Pp. 175-194. 
Ulyshen, M.D., Duan, J.J., and Bauer, L.S. 2010. Interactions between Spathius agrili (Hymenoptera: Braconidae) and Tetrastichus planipennisi (Hymenoptera: Eulophidae), larval parasitoids of Agrilus planipennis (Coleoptera: Buprestidae). Biological Control, 52: 188-193. doi:10.1016/j. biocontrol.2009.10.017.

van Driesche, R., Hoddle, M., and Center, T. 2008. Control of pests and weeds by natural enemies: an introduction to biological control. Wiley- Blackwell Publishing, Hoboken, New Jersey, United States of America.

van Frankenhuyzen, K., Lucarotti, C., and Lavallée, R. 2015. Canadian contributions to forest insect pathology and to the use of pathogens in forest pest management. The Canadian Entomologist, doi:10.4039/tce.2015.20.

Varley, G.C. and Gradwell, G.R. 1968. Population models for the winter moth. In Insect abundance. Edited by T.R.E. Southwood. Blackwell Scientific, Oxford, United Kingdom. Pp. 132-142.

Varty, I.W. 1984. D. Testing of parasitoids. In Biological control programmes against insects and weeds in Canada 1969-1980. Edited by J.S. Kelleher and M.A. Hulme. Commonwealth Agricultural Bureaux, Farnham Royal, Slough, United Kingdom. Pp. 267-272.

Wallace, D.R. 1995. Classical biological control. In Forest insect pests in Canada. Edited by J.A. Armstrong and W.G.H. Ives. Canadian Forest Service, Natural Resources Canada, Ottawa, Ontario, Canada. Pp. 385-396.

West, R.J., Dixon, P.L., Quednau, F.W., and Lim, K.P. 2002a. Pristiphora geniculata (Hartig), mountain ash sawfly (Hymenoptera: Tenthredinidae). In Biological control programmes in Canada, 1981-2000. Edited by P.G. Mason and J.T. Huber. CABI Publishing, Wallingford, United Kingdom. Pp. 228-230.
West, R.J., Dixon, P.L., Quednau, F.W., Lim, K.P., and Hiscock, K. 1994. Establishment of Olesicampe geniculate Quednau and Lim (Hymenoptera: Ichneumonidae) to control the mountain ash sawfly, Pristiphora geniculata (Hartig) (Hymenoptera: Tenthredinidae) in Newfoundland. The Canadian Entomologist, 126: 7-11. doi:10.4039/Ent1267-1.

West, R.J. and Kenis, M. 1997. Screening four exotic parasitoids as potential controls for the eastern hemlock looper, Lambdina fiscellaria fiscellaria (Guenée) (Lepidoptera: Geometridae). The Canadian Entomologist, 129: 831-841. doi:10.4039/ Ent129831-5.

West, R.J., Kenis, M., Bouchier, R.S., Smith, S.M., and Butt, G.W. 2002b. Zeiraphera canadensis Mutuura and Freeman, spruce bud moth (Lepidoptera: Tortricideae). In Biological control programmes in Canada, 1981-2000. Edited by P.G. Mason and J.T. Huber. CABI Publishing, Wallingford, United Kingdom. Pp. 279-283.

Wong, H.R. 1974. The identification and origin of the strains of the larch sawfly, Pristiphora erichsonii (Hymenoptera: Tenthredinidae), in North America. The Canadian Entomologist, 106: 1121-1131. doi:10.4039/Ent1061121-11.

Yang, Z.Q., Strazanac, J.S., Yao, Y.X., and Wang, X.Y. 2006. A new species of emerald ash borer parasitoid from China belonging to the genus Tetrastichus Haliday (Hymenoptera: Eulophidae). Proceedings of the Entomological Society of Washington, 108: 550-558.

Zhang, Y.Z., Huang, D.W., Zhao, T.H., Liu, H.P., and Bauer, L.S. 2005. Two new species of egg parasitoids (Hymenoptera: Encyrtidae) of woodboring beetle pests from China. Phytoparasitica, 33: 253-260. doi:10.1007/BF02979863. 